\title{
Making Sense of Antitrust Petitioning Immunity
}

\author{
Einer Elhauge $\dagger$
}

Courts have struggled to produce a coherent doctrine governing when petitioners, such as lobbyists and litigants, are immune from antitrust liability. A variety of apparently conflicting exceptions and requirements permeate Supreme Court decisions in the field. In this Article, Professor Elhauge utilizes a functional process approach to identify factors the Court has implicitly considered in determining whether immunity applies. These factors turn critically on the incentive structure of the relevant decisionmaker: in particular, on whether the decisionmaker who imposed the restraint at issue had an objective financial interest in the restraint's anticompetitive consequences. Restraints produced by such a financially interested decisionmaking process, the Article argues, are and should be denied antitrust immunity unless the activity producing the restraint does not involve market behavior and is not separable from otherwise valid input into a governmental process of decisionmaking. These functional process considerations are shown to explain the outcome in every Supreme Court case adjudicating antitrust petitioning immunity issues. Adherence to a functional process approach, Professor Elhauge concludes, will facilitate resolution of many questions and anomalies regarding petitioning immunity doctrine and permit a more accurate understanding of the relationship between antitrust petitioning immunity and the related doctrine of state action immunity.

For most of its history, the doctrine immunizing petitioning activity from antitrust liability has perversely coupled a sweepnig general imnulnity with equally sweeping exceptions. This period was dominated by a trilogy of cases-Noerr, ${ }^{1}$ Pennington, ${ }^{2}$ and California Motor ${ }^{3}$ - that embraced this seemingly simple principle: "Joint efforts to influence public officials do not violate the antitrust laws even though intended to

$\dagger$ Professor of Law, Boalt Hall School of Law, University of California, Berkeley. A.B. 1982, Harvard College; J.D. 1986, Harvard Law School. I am grateful for comments from Gary Minda and Stephen Calkins and financial support from the Boalt Hall Fund and the John M. Olin Foundation.

1. Eastern R.R. Presidents Conference v. Noerr Motor Freight, 365 U.S. 127 (1961).

2. United Mine Workers v. Pennington, 381 U.S. 657 (1965).

3. California Motor Transp. Co. v. Trucking Unlimited, 404 U.S. 508 (1972). 
eliminate competition."4 But this pristine principle was pockmarked with exceptions. Immunity did not apply when the efforts to influence public officials were a "sham,"s a concept stretched to include "forms of illegal and reprehensible practice," even if they succeeded in influencing governmental action. ${ }^{6}$ Nor did the immunity apply to petitioning that involved "commercial activity."7 And the Court's dicta recognized a "conspiracy" exception, which demed immunity when a private actor conspired with the government to restrain trade. ${ }^{8}$

Perhaps embarrassed by its handiwork, the Court essentially ignored the issue for the sixteen years following California Motor, leaving the lower courts and litigants to struggle with the resulting doctrinal hodgepodge. The doctrine became increasingly unstable. The sham exception turned mto a catchall to cover whatever forms of petitioning adjudicatimg courts deemed "improper." The commercial exception was sometimes apphed and sometimes rejected in cases where either the petitioning or the desired governmental action was deemed to be "commercial," a term that remained ill-defined. ${ }^{10}$ Even more open-ended was the conspiracy exception, for a conspiracy of sorts could be alleged whenever petitioning was successful. And some lower courts recognized other vague exceptions for petitioning that influenced policy "implementation" rather than policy making, " and for when the activity was not "direct" petitioning but "preliminary" to it. 12

The problem was more than a failure to set forth clear general rules for defiming the scope of the immumity. The larger problem was that, as the exceptions were defined, adjudication consisted of pasting a conclusory label on the petitioning activity at issue. Implicit factors and pohicy judgments no doubt guided many courts in deciding whether a given activity was improper and a "sham," and in deciding whether the

4. Pennington, 381 U.S. at 670; see also California Motor, 404 U.S. at 510-11; Noerr, 365 U.S. at $136-38$.

5. Noerr, 365 U.S. at 144.

6. California Motor, 404 U.S. at 511-13; see also Walker Process Equip., Inc. v. Food Mach. \& Chem. Corp., 382 U.S. 172 (1965) (holding that antitrust liability could be imposed for a party's actions in fraudulently obtaining and enforcing a patent).

7. Continental Ore Co. v. Union Carbide \& Carbon Corp., 370 U.S. 690, 707-08 (1962); see also Noerr, 365 U.S. at 137, 140-41 (distinguishing immune political activities from non-immune business activities).

8. California Motor, 404 U.S. at 513; Pennington, 381 U.S. at 671 \& n.4.

9. See, e.g., Stephen Calkins, Developments in Antitrust and the First Amendment: The Disaggregation of Noerr, 57 ANTITRUST L.J. 327, 339 \& n.63 (collecting sources).

10. See Phillip E. AReeda \& Herbert Hovenkamp, ANTITrust LAw $₫$ 206', at 75-79 (Supp. 1991); Calkins, supra note 9, at 356-58; James D. Hurwitz, Abuse of Governmental Processes, the First Amendment, and the Boundaries of Noerr, 74 GEo. L.J. 65, $85-88$ (1985); Lawrence A. Sullivan, Developments in the Noerr Doctrine, 56 ANTITRUST L.J. 361, 366-67 (1987).

11. See Earl W. Kintner \& Joseph P. Bauer, Antitrust Exemptions for Private Requests for Governmental Action: A Critical Analysis of the Noerr-Pennington Doctrine, 17 U.C. DAVIS L. REv. 549,563 n.56 (1984) (collecting cases).

12. Id. at 568-69 \& nn.80-81 (collecting cases); see Calkins, supra note 9, at 345 n.92 (same). 
commercial, conspiracy, and other exceptions applied. But these factors and policy judgments were not articulated. Consequently, the process of case-by-case adjudication did not redress the absence of general rules by producing precedents that could provide useful guidance. Instead, it produced doctrinal inconsistency, ${ }^{13}$ prolonged uncertainty, ${ }^{14}$ and everincreasing litigation. ${ }^{15}$

Dissatisfied with this doctrinal muddle, the Supreme Court has in the last four years issued a new trilogy of cases-Allied Tube, ${ }^{16}$ Trial Lawyers, ${ }^{17}$ and $O m n i{ }^{18}$ - that casts aside the old trilogy's uneasy compromise between a broad immunity and its open-ended exceptions. This new trilogy drastically shrinks the sham and conspiracy exceptions. The sham exception, the Court has made clear, no longer includes improper petitioning activities if those activities are genuinely intended to influence the government. ${ }^{19}$ And the conspiracy exception has been rejected, with the possible exception of cases where the government is acting as a market participant. ${ }^{20}$

At the same time, the new trilogy circumscribes the sweep of the affirmative immunity. It emphasizes that "the Noerr doctrine does not extend to 'every concerted effort that is genuinely intended to influence governmental action.' "21 As if to underscore the point, two of the new cases denied inınunity to petitioning efforts that were not only genuinely intended to influence governmental action, but successful in doing so. ${ }^{22}$ The scope of antitrust petitioning inımunity now "depends . . . on the source, context, and nature of the anticompetitive restraint at issue."23

The Court's new focus on the "source, context, and nature" of restraints has been roundly criticized for conipounding instead of clarifying the doctrinal confusion. ${ }^{24}$ And it cannot be denied that this new for-

13. See, e.g., Calkins, supra note 9, at 338-39; Sullivan, supra note 10, at 368 .

14. See, e.g., Daniel R. Fischel, Antitrust Liability for Attempts to Influence Government Action: The Basis and Limits of the Noerr-Penuington Doctrine, 45 U. CHI. L. REv. 80, 80-81 (1977); Kintner \& Bauer, supra note 11, at 553.

15. To provide a rough sense of the magnitude and upward trend of litigation about antitrust petitioning immunity, I conducted a Westlaw search for federal opinions citing Noerr. This search uncovered a total of 718 cases decided between 1961-90. Only 75 of these opinions came down during 1961-70; 238 came down during 1971-80; and 405 came down during 1981-90.

16. Allied Tube \& Conduit Corp. v. Indian Head, Inc., 486 U.S. 492 (1988).

17. FTC v. Superior Court Trial Lawyers Ass'n, 493 U.S. 411 (1990).

18. City of Columbia v. Omni Outdoor Advertising, 111 S. Ct. 1344 (1991).

19. See id. at 1354-55; Allied Tube, 486 U.S. at 507 n.10.

20. Omni, $111 \mathrm{~S}$. Ct. at $1351-53$.

21. Trial Lawyers, 493 U.S. at 425 (quoting Allied Tube, 486 U.S. at 503).

22. See id. at $\mathbf{4 1 8}$ (denying immunity to petitioning efforts that succeeded in getting a city council to increase the prices paid to the defendants); Allied Tube, 486 U.S. at 502-03 (denying immunity to petitioning efforts that led to widespread adoption by state and local governments of an electrical code hurting defendants' competitors).

23. Allied Tube, 486 U.S. at 499; see also Trial Lawyers, 493 U.S. at 424-25 (denying immunity where the source of the challenged restraint was not public action).

24. See, e.g., Allied Tube, 486 U.S. at 513 (White, J., dissenting); AReeda \& HovenKamp, 
mulation is not by itself terribly informative. Which sources, contexts, and natures provide immunity, and which do not? The new trilogy defines some of the relevant factors, but leaves others open.

What the new doctrinal framework does do, which the old doctrinal framework did not, is encourage courts to articulate the factors and policy judgments underlying their decisions. This might, in the long run, produce precedents that can provide greater doctrinal coherence. The new doctrinal framework also invites legal academics to see what factors and policy judgments we can identify in the cases to bring thein into soine predictable order.

The tine has come, in short, to see whether we can make any unore sense of antitrust petitioming immunity after the new trilogy than we could after the old one. I argue that we can under a functional process approacli. Differences in the incentive structures underlying the decisionmaking processes that produce the restraints explain and justify why soine restraints receive immunity and others do not. This arguinent builds on my prior article describing the process ideals underlying antitrust state action immunity. ${ }^{25}$ I conclude that, as with state action immunity, petitioning immunity reflects the Court's inplicit functional process views about how best to set the boundaries between the conipetitive and governmental processes.

A inore precise statenient of the conclusion would be this: under the Court's implicit process view, antitrust innunity does not apply-and the restraint at issue inust be subjected to a coinpetitive process regulated by antitrust ground rules-if the decisioninaker who iniposed the restraint has an objective financial interest in the restraint's anticoinpetitive consequences, unless the activity producing the restraint neither involves inarket behavior nor is separable froin otherwise valid input into the governinental process. Explaining the concrete ineaning of this conclusion, and low it conforins to a coherent functional process position, will be the task of this Article.

Part I analyzes the Suprenie Court's opinions and the doctrinal difficulties they produce in order to establisl the need to forinulate a policy foundation for tlie doctrine. Part II derives the basic functional process view that underlies the results in the cases, einploys that view to resolve soine doctrinal anomalies, and defends it against the interest group theory critique. Part III assesses the special issues posed by inarket restraints that coerce governmental action, and explains why the Court looks at objective incentives rather than subjective inotives. Part IV then tackles the tricky issues posed by private action that both directly

supra note 10, If 206.2, at 89; Calkins, supra note 9, at 327, 337; Gary Minda, Interest Groups, Political Freedom, and Antitrust: A Modern Reassessment of the Noerr-Pennington Doctrine, 41 HASTINGS L.J. 905, $977-78$ \& n.264 (1990).

25. Einer R. Elhauge, The Scope of Antitrust Process, 104 Harv. L. Rev. 667 (1991). 
restrains trade and provides noncoercive input into the governmental process. Finally, Part V explores the limited circumstances in which petitioners can be liable for restraints imposed by governmental decisionmakers.

\section{I}

The Opinions AND Their Resulting Doctrinal DifFiculties

\section{A. The Old Trilogy}

Antitrust petitioning immunity began with the famous case of Eastern Railroad Presidents Conference v. Noerr Motor Freight. ${ }^{26}$ Noerr concerned a publicity campaign conducted by a group of railroads against truckers. The campaign had, and was intended to have, two mam effects. First, it influenced government officials to enact or retain laws that made it hard for truckers to compete with the railroads. ${ }^{27} \mathrm{Sec}-$ ond, the campaign's adverse publicity directly impaired relations between truckers and their customers. ${ }^{28}$

Justice Black's opinion for the Court quickly concluded that the defendant railroads were immune from liability for the first effect, ${ }^{29}$ which would seem to follow from antitrust's immunity for state action. The more interesting issue was whether the defendant should have immunity for the second direct effect. Without the aim to influence governmental action, a conspiracy to falsely disparage a competitor and hamper its customer relations would normally be subject to antitrust liability. But the Court decided that the defendants should be immune from liability for this effect because it was "imcidental" to "pohitical" activities genuinely intended to influence the government. ${ }^{30}$

Along the way, the Noerr Court made two things clear. First, it did not matter that the defendants were inotivated by their financial interest in what law would prevail. ${ }^{31}$ Second, it did not matter that the methods of political lobbying were unethical or deceptive. ${ }^{32}$

But the Court's opmion left other issues unresolved. Questions were raised by the Court's intimations that immunity might not apply if the activities used to influence the government involved not "political activity" but "business activity." 33 How precisely could one tell the differ-

\footnotetext{
26. 365 U.S. 127 (1961).

27. Id. at 129-30.

28. Id. at $129,133,142$.

29. Id. at 135-36.

30. Id. at $142-44$.

31. See id. at $138-40$.

32. See id. at 140-42.

33. Id. at 136-37, 140-41.
} 
ence? Is there immumity for activity that is neither "political" nor "business" in nature? The opinion did not address those questions.

The case also raised questions about the scope of the immunity for direct effects incidental to genume pohtical petitioning. What does it take for these direct effects to be considered "incidental" to the petitioning? Is it enough that the effects flowed from efforts designed to influence the government? Or is the mcidental test tantamount to a least restrictive alternative test, whereby the defendants are immune for direct injuries only if they have chosen the method of petitioning that imposes the least direct injury?

The Supreme Court next returned to the issue of antitrust petitioning immunity in Continental Ore Co. v. Union Carbide \& Carbon Corp. ${ }^{34}$ This case is usually left out of the Noerr trilogy, ${ }^{35}$ no doubt because it contains only a short aside on the issue, but it nonetheless established an important precedent.

The defendant in Continental Ore was a producer of vanadium. The defendant's corporate subsidiary had been appointed an agent of the Canadian government and given "discretionary agency power to purchase and allocate to Canadian industries all vanadium products."36 The defendant sought immumity under Noerr for its efforts to have its subsidiary use this governmental authority to exclude the defendant's competitors from selling vanadium on the Canadian market. The Supreme Court rejected this argnment, concluding that the defendant's actions were "private commercial activity" outside the scope of Noerr. ${ }^{37}$

Unfortunately, this conclusion was unadorned with reasoning. Justice White's laconic opinion for the Court did not bother to explain what made the activities private commercial activity. The subsidiary influenced by the defendant was a governmental agent exercising governmental authority. And while the governmental authority did involve the purchase and resale of vanadium, this authority was essentially regulatory, designed to set a price ceiling during wartime and to allocate the metal in a non-1narket fashion in order to further strategic war aims. Why is this "commercial" rather than "political" or "regulatory"?

United Mine Workers v. Pennington, ${ }^{38}$ the next case in the official trilogy, eliminated one possible answer to this question. Pennington involved, among other things, defendants' petitioning efforts to influence coal purchases by the Tennessee Valley Authority (TVA) to the detriment of the defendants' competitors. The Court concluded that such an

34. 370 U.S. 690 (1962).

35. For sources including only Noerr, Pennington, and California Motor in the original trilogy, see, e.g., Milton Handler \& Richard A. De Sevo, The Noerr Doctrine and Its Sham Exception, 6 Cardozo L. Rev. 1, 3-7 (1984); Hurwitz, supra note 10, at 78 \& n.42.

36. Continental Ore, 370 U.S. at $703 \mathrm{n.11}$; see id. at 695, 702-04.

37. Id. at 707-08.

38. 381 U.S. 657 (1965). 
effort to influence "public officials" was immune from antitrust liability. $^{39}$ Thus, whatever else suffices to constitute commercial activity within the commercial exception, efforts to influence the government's actions as a market participant do not.

The puzzling feature of Pennington is that it distinguished Continental Ore on the ground that there the influenced agent "was not a public official but the wholly owned subsidiary of an American corporation alleged to be a principal actor in the conspiracy."40 But being a public official and being a subsidiary are not mutually exclusive. And the Court opinion, another Delplic effort by Justice White, does not explain how the Court squared its conclusion that Continental Ore did not involve a "public official" with the fact that the agent there exercised a governmental authority delegated to it by the Metals Controller of the Canadian government. ${ }^{41}$

In the end, then, Pennington provided no useful criteria for determining how to apply the commercial exception. Moreover, by stressing that the influenced public official in Pennington was not alleged to be a "co-conspirator," 42 the opinion spawned what would become a troublesome and ill-defined conspiracy exception.

The next relevant case is, like Continental Ore, not considered part of the Noerr trilogy, no doubt because it does not even mention Noerr. Nonetheless, in Walker Process Equipment, Inc. v. Food Machinery \& Chemical Corp. ${ }^{43}$ the Court estabhished the important principle that obtaining admimistrative and judicial action througl fraudulent petitioning could sometimes result $\mathrm{m}$ antitrust liability.

The defendant in Walker Process allegedly obtained a patent by denying knowledge of anyone else using the invention when $\dot{m}$ fact the defendant knew the plaintiff had been using it. ${ }^{44}$ The plaintiff sued under the Sherinan Act, alleging that the existence and enforcement of the patent liad deprived the plaintiff of business it would have otherwise enjoyed.

The Court held that, if true, these allegations would establish a Sherman Act violation. An implicit holding was thus that Noerr immunity did not apply even though the defendant's actions, fraudulent though they may have been, were definitely intended to secure governmental action. Indeed, those actions succeeded in obtaming at least administrative action. But because the Court never directly addressed Noerr, the decision left unclear why Noerr immunity did not apply. Did
39. Id. at 670 .
40. Id. at 671 n.4.
41. See Continental Ore, 370 U.S. at 702 n.11.
42. Pennington, 381 U.S. at 671 \& n.4.
43. 382 U.S. 172 (1965).
44. Id. at 174. 
the use of fraud make the efforts to procure governmental action a "sham"? Was immunity denied because the petitioning activity did not seek "political" action but rather sought administrative and judicial adjudication of a factual issue?

These questions provide the backdrop for the final case in the Noerr trilogy: California Motor Transport Co. v. Trucking Unlimited. ${ }^{45}$ In California Motor, the defendants allegedly conspired to institute legal proceedings to prevent their competitors from acquiring operating rights. The defendants' strategy was allegedly to harass their conipetitors by instituting these proceedings " "with or without probable cause, and regardless of the nierits of the cases." "46 This did not niean that all, or even most, of the proceedings were baseless. On the contrary, the defendants had won twenty-one out of forty cases. ${ }^{47}$ Rather, the crux of the conplaint was that the defendants were instigating litigation automatically, without regard to whether the litigation had merit or not, in order to impose costs and delays on their conipetitors.

The California Motor Court first answered one of the questions raised in Walker Process by making clear that Noerr innunity applied not only to efforts to influence legislative and executive action, but also to efforts to influence administrative and judicial action. ${ }^{48}$ Noerr inununity was, in other words, not an inimunity limited to "political activities," but rather a general inımunity for efforts to petition any of the branches of government.

But the California Motor Court coupled this broadening of the immunity with a broadening of the shan exception. Given that the defendants' success rate was over fifty percent, it could not be denied that the suits were genuine efforts to influence adjudicators. ${ }^{49}$ And a shan1 exception truly limited to situations where no genuine effort was made to influence the government could not explain the decision in Walker Process. Justice Douglas' breezy opinion for the Court superficially reconciled this tension by asserting that the shan exception enconipassed "forms of illegal and reprehensible practice which inay corrupt the adninistrative or judicial processes." 50 As exaniples, the opinion cited lymg to an adjudicator or patent officer, conspiring with a licensing authority, and bribing a purchasing agent. ${ }^{51}$ More specifically, the Court

\footnotetext{
45. 404 U.S. 508 (1972).

46. Id. at 512 .

47. Trucking Unlimited v. California Motor Transp. Co., 1967 Trade Cas. (CCH) \ 72,298, at 84,744 (N.D. Cal.), rev'd on other grounds, 432 F.2d 755 (9th Cir. 1970), aff'd on other grounds, 404 U.S. 508 (1972).

48. See California Motor, 404 U.S. at 510.

49. Cf. Noerr, 365 U.S. at 144 (holding the sham limitation inapplicable because the challenged "effort was not only genuine but also highly successful").

50. California Motor, 404 U.S. at 513.

51. Id. at 512-13.
} 
concluded that the activity at issue-a pattern of making repetitive claims regardless of the merits in order to impose costs on the other litigant-constituted a sham. ${ }^{52}$

While one can sympathize with the Court's desire to deny antitrust immunity to such abusive practices, its use of the sham exception to accomplish the result was quite unfortunate. Having deprived the word "sham" of its natural meaning and of the meaning assigned to it by Noerr, it became nothing more than a catchall for whatever activities courts deemed improper.

To be sure, the Court made clear that political activities needed a wider berth of immunity, and that activities deemed a sham in the adjudicative process would not necessarily be deemed a sham im the pohitical process. ${ }^{53}$ But other than establishing that antitrust petitioning immunity varied with the context of the petitioning activity, this clarified very little. And it hardly provided the sort of clear guidance to which First Amendment activities are normally entitled because of concern that legal ambiguity will produce a chilling effect.

\section{B. The Modern Trilogy}

Having left the lower courts to grapple unsuccessfully with this doctrinal morass for sixteen years, the Court returned to the issue four years ago in Allied Tube \& Conduit Corp. v. Indian Head, Inc. ${ }^{54}$ In that case, steel producers packed the annual meeting of a private standard-setting association with employees and spouses in order to secure a majority vote for a version of the association's electrical code that excluded plastic conduit manufactured by competitors. The question was whether antitrust petitioning immunity should apply because the association's electrical code was routinely adopted into law by state and local goveruments.

The Court could have, as Justice White's dissent did, simply applied the general immunity with open-ended exceptions approach, and made a conclusory decision that the conduct either was (or was not) a "sham." 55 Instead, in an opinion by Justice Brennan, the Court abandoned that approach, explicitly rejecting the proposition that the sham exception covered genuine efforts to influence the government through "improper means" or "flagrant abuse." As the Court noted, this loose use of the word "sham" rendered it no more than a contentless label, which obscured the factors underlying court decisions. ${ }^{57}$ Indeed, a telling illus-

52. See id.; see also Otter Tail Power Co. v. United States, 410 U.S. 366, 380 (1973) (stating that "repetitive lawsuits carrying the hallmark of insubstantial claims" fall within the sham exception).

53. California Motor, 404 U.S. at 512.

54. 486 U.S. 492 (1988).

55. See id. at 516 (White, J., dissenting).

56. 486 U.S. at 508 n. 10.

57. See id. Claims of a "sham" had become so devoid of meaning that courts were holding 
tration of the problem was ironically provided by White's dissent and the leading appellate proponent of this open-ended interpretation of the sham exception: each had reached directly contrary conclusions about the conduct in Allied Tube-one concluding it was a sham, and the other concluding it was not-without ever identifying the factors that led to their different conclusions. ${ }^{58}$

From now on, the Allied Tube Court stressed, the sham exception would only cover "activity that was not genuinely intended to influence governmental action." 59 Unfortunately, with the sham exception properly limited, the Court had no ready doctrinal tools for grappling with the case at hand.

The Court could not deny that the effort to influence government action was "genuine," as the association's code was widely adopted into legislation by state and local governments. ${ }^{60}$ Nor could it claim the direct effects on the Code were not "incidental" to the petitioning efforts. Influencing the association's code was probably the "most effective means" of influencing legislation on the topic, and the effects of the "widespread" legislative adoption likely dwarfed the direct effects of the association code on the marketplace. ${ }^{61}$

At the same time, the case at hand involved firms exercising decisionmaking authority to formulate an association product standard that would in effect bind the association's members in an agreement to boycott a product of the firms' competitors. It was inconceivable that such a horizontal agreeinent about market behavior could be iininunized from antitrust hability solely because the government might be persuaded by the example to adopt the same inarket restraint into law itself. If antitrust petitioning immumity applied to concerted market behavior that genuinely influenced the government, then a variety of bizarre results would follow: "[C]ompetitors would be free to enter into liorizontal price agreements as long as they wished to propose that price as an appropriate level for governinental ratemaking or price supports. Horizontal conspiracies or boycotts designed to exact higher prices or otler economic advantages from the governinent would be inmunized . ..."62

The Court was thus faced witl tlie difficult task of erecting a new doctrinal edifice to replace the shaky one it had razed. It attempted to do so by declaring that antitrust petitioning immunity depended on the

that alleging a sham failed to provide a defendant with adequate notice of a plaintiff's claim. See AREeda \& HovenKamp, supra note 10, ๆ 203.4b, at 55-56 (collecting cases).

58. Compare Sessions Tank Liners v. Joor Mfg., 827 F.2d 458, 465 (9th Cir. 1987) (sham), vacated, 487 U.S. 1213 (1988), with Allied Tube, 486 U.S. at 516 (White, J. dissenting) (not a sham).

59. Allied Tube, 486 U.S. at $508 \mathrm{n} .10$; see also id. at $500 \mathrm{n} .4$. This position was reaffirmed in City of Columbia v. Omni Outdoor Advertising, 111 S. Ct. 1344, 1354 (1991).

60. See Allied Tube, 486 U.S. at 502.

61. Id. at 502-03.

62. Id. at 503 (citations omitted). 
"source, context, and nature" of the anticompetitive restraint sought to be remedied. ${ }^{63}$

The rule Allied Tube laid down was relatively straightforward when the source of the restramt was "valid governmental action."64 In such a case, the immunity of those urging the governmental action is "absolute." 65 Thus, the defendants im Allied Tube had no liability for the market injuries resulting from the governmental adoption of the association's code. $^{66}$

Complexities arose, however, where the direct source of the restraint was "private action," in the sense that the restraint would occur whether or not the government took action. Antitrust petitioning immunity applied to such private restraints only if the restraint was (1) "incidental" to a (2) "genuine" and (3) "valid" effort to influence the government. ${ }^{67}$ In Allied Tube, as noted above, the "imcidental" and "genuine" prongs of this three-part test were amply satisfied. The determinative question was whether the effort was "valid." Such determinations of validity, the Court stated, depend on the context and nature of the activity. ${ }^{68}$

In the case at hand, the Court concluded, the context and nature of defendants' conduct made it "commercial activity" that did not enjoy antitrust petitionimg immunity. ${ }^{69}$ It based this conclusion on two factors: (1) the conduct occurred in the context of a private standard-setting association where the normal rules of legality are provided by antitrust law itself; and (2) the nature of the conduct was exercising decisionmaking authority over market behavior, namely agreeing not to trade in plastic conduit. $^{70}$

This was certainly an inuprovement on the loose Continental Ore commercial exception; at least some factors sufficient to lose immunity had been spelled out. But unfortunately, this approach did not answer the question that the dissent and others wanted answered: what other contexts and natures would also be denied immunity? Because the Court did not list the contexts and natures that did and did not nerit immunity, its approach left the scope of petitioning immunity ill-defined. Worse, because the Court did not articulate why the nature and context of the conduct in Allied Tube meant it deserved no immunity, it provided no underlying policy to help guide the resolution of doctrinal ambiguities and gaps.

The next case in the new trilogy was FTC v. Superior Court Trial
63. Id. at 499 .
64. Id.
65. Id.
66. Id. at 498 \& n.2, 500 .
67. Id. at $499-500$ \& n.4.
68. Id. at 499-500.
69. Id. at $505-07$ \& n. 10 .
70. Id. at 506-07. 
Lawyers Ass'n. ${ }^{71}$ In this case, an association of trial lawyers had collectively agreed not to represent indigent criminal defendants until the District of Columbia increased the fees it paid the lawyers for such representation. In response the city agreed to pay the fees the boycotters requested. ${ }^{72}$ The trial lawyers claimed antitrust petitioning immunity for their boycott on the ground that it was aimed at securing governmental action.

The Supreme Court denied immunity. Justice Stevens' opinion for the Court offered the following explanation:

[I] $\mathrm{n}$ the Noerr case the alleged restraint of trade was the intended consequence of public action; in this case the boycott was the means by which [the trial lawyers] sought to obtain favorable legislation. The restraint of trade that was implemented while the boycott lasted would have had precisely the same anticompetitive consequences during that period even if no legislation had been enacted. In Noerr, the desired legislation would have created the restraint on the truckers' competition; in this case the emergency legislative response to the boycott put an end to the restraint. $^{73}$

This would be inore illuminating but for the fact that the Court's characterization of Noerr was inaccurate. As we saw in Section I.A, Noerr did not involve only restraints caused by public action. The publicity campaign had also restrained trade directly by impairing relations between truckers and their customers. ${ }^{74}$ This restraint was a consequence of private action rather than public action in precisely the sense the Trial Lawyers Court meant: it would have had the same anticoinpetitive effects whether or not the governinent had acted. ${ }^{75}$ Thus, the means/consequence distinction did not explain the different holdings in Noerr and Trial Lawyers.

The only other reasoning Justice Stevens offered for the Court's conclusion was Allied Tube's dicta that horizontal price-fixing, boycotts, or output restrictions could not be immuinzed even if genuinely intended to influence governmental action. ${ }^{76}$ This provided no general delineation of the scope of antitrust petitioning immunity. But it did make two important contributions to the doctrine. First, it elevated this dicta to holding. Second, it established that collective decisionmaking over market behavior (the second Allied Tube factor) would, at least if used as the means to influence governmental action, suffice to deprive the activity of immunity

71. 493 U.S. 411 (1990).

72. Id. at 418.

73. Id. at $424-25$.

74. Eastern R.R. Presidents Conference v. Noerr Motor Freight, 365 U.S. 127, 129, 133, 142 (1961).

75. Id. at 133 (stating that the campaign "injured the truckers in ways unrelated to the passage or enforcement of law").

76. Trial Lawyers, 493 U.S. at 425 (quoting Allied Tube \& Conduit Corp. v. Indian Head, Inc., 486 U.S. 492, 503 (1988)). 
even if the activity occurred in a public, highly political context. ${ }^{77}$

The last case in the new trilogy is City of Columbia v. Omni Outdoor Advertising. ${ }^{78}$ The defendant, the jury found, had conspired with inunicipal officials to obtain the enactinent of zoning ordinances that restricted billboard construction by the defendant's competitor.

The Court decided that, with the possible exception of a case where the government acted as a market participant, no conspiracy exception should be recognized to antitrust's immunity for either state action or petitioning activity. ${ }^{79}$ A general conspiracy exception, the Court reasoned, would swallow the immunity because any governmental action could be said to result from an agreenient between government officials and those who petitioned for the action. ${ }^{80}$

This helped clarify the scope of the conspiracy exception. Unfortunately, Justice Scalia's opinion for the Court muddied the waters when it canie to discussing the plaintiff's argument that the sham exception should apply. The opimion stated that the shain exception "encompasses situations in which persons use the governinental process-as opposed to the outcome of that process-as an anticompetitive weapon."81 But, like the ineans/consequence distimction put forth in Trial Lawyers, this reasoming is unsatisfactory: it does not explain why immumity apphied in Noerr when the process of petitioming the government was used to inflict direct injuries.

Justice Scalia's opinion tried to avoid this problem through two inaneuvers. The first was to imply that the defendant's motives were determinative. The opinion stated, "Although [the defendant] indisputably set out to disrupt [the plaintiff's] business relationships, it sought to do so not through the very process of lobbying ... but rather through the ultimate product of that lobbying and consideration . . . ."82

But these motives are not mutually exclusive. In Noerr and Allied Tube, the defendants were acknowledged to have both the motive of securing governinental action and the inotive of directly harming coinpetitors through the acts of petitioning. ${ }^{83}$ One suspects that had the jury been asked to make findings on the issue, the Omni defendants might also have been found to have such inixed motives.

In any event, most petitioners are unlikely to have the purity of

77. The Court also established that it would suffice if the collective market behavior was a per se antitrust violation: possession of market power was not necessary to lose antitrust immunity. Id. at $428-36$.

78. 111 S. Ct. 1344 (1991).

79. Id. at $1351,1353,1355-56$.

80. Id. at 1351 (citing AREeDA \& HovenKAMP, supra note 10, ๆ 203.3b, at 34 \& n.l (Supp. 1989); Elhauge, supra note 25, at 704-05).

81. Id. at 1354 .

82. Id.

83. Allied Tube, 486 U.S. at 502-03; Eastern R.R. Presidents Conference v. Noerr Motor Freight, 365 U.S. 127, 142, 144 (1961). 
motive attributed by Justice Scalia to the defendant in Omni. Petitioners seeking governmental action to stifle their competitors are (like the peti'tioners in Noerr and Allied Tube) likely to take pleasure in any expense, delay, and interference their activity directly inflicts on competitors. The Omni analysis does nothing to help guide courts in these mixed motive cases. As Noerr and Allied Tube demonstrate, immunity or non-immunity remain possible outcomes.

The second maneuver was to suggest that the exception for injuring competitors through the process of petitioning applied only when the defendant had "no expectation of achieving" the desired governmental result. $^{84}$ This, at least after Allied Tube, correctly describes the modern sham exception. But the cases that have denied immunity where the petitioning process directly injures competition-California Motor, Walker Process, Allied Tube, and Trial Lawyers-do not fit within this definition of a sham.

Justice Scalia mistakenly thought that at least California Motor could be squeezed imto the modern sham exception. His Omni opinion noted that, despite language in California Motor about improper petitioning activities being shams, the actual case involved allegations that the defendants litigated " with or without probable cause, and regardless of the merits of the cases." "85 Justice Scalia concluded from this that the defendants in California Motor had made no genuine effort to influence the courts, and that any language about an immunity exception for genuine but improper efforts to influence the government could be ignored as dicta. ${ }^{86}$

However, the factual premise for Scalia's analysis-that the defendants in California Motor had no expectation of obtaining favorable governmental action-is false. As previously noted, the defendants had in fact prevailed in twenty-one out of forty cases. ${ }^{87}$ Not only did their litigations have a genuine chance of success, but they were batting over .500! This explains why Justice Douglas felt obliged in his California Motor opinion to assess the antitrust immunity for various genuine but invalid methods of petitioning.

California Motor denied immunity not because the petitioning there was not genuinely intended to secure governmental action, but because the petitioning was, under traditional adjudicative norms, an abuse of process: that is, litigation brought in order to impose costs and delays. Whether such a motive should be sufficient to lose immunity even if the defendant also has a motive of winning the adjudication, or whether the

84. Omni, $111 \mathrm{~S}$. Ct. at $1354-55$.

85. Id. at 1355 (quoting California Motor Transp. Co. v. Trucking Unlimited, 404 U.S. 508, 512 (1972)).

86. See id.

87. See supra text accompanying note 47. 
"predominant" motive should govern, are complicated questions that I will discuss below. ${ }^{88}$ But they are questions that Omni's facile characterization does nothing to help answer.

One might be tempted to read Omni as overruling the holding in California Motor ${ }^{89}$ to establish a new rule that genuine efforts to secure governmental action are always immune, ${ }^{90}$ with a possible exception for cases where the petitioner seeks to influence the government's actions as a market participant. ${ }^{91}$ But such a sweeping expansion of antitrust petitioning ininunity would have to overrule nore than California Motor: it would also have to overrule Walker Process, Allied Tube, and probably Trial Lawyers. ${ }^{92}$ In all of those cases, the defendants received no antitrust inimunity even though they genuinely desired, and successfully obtained, favorable governmental action.

Unfortunately, Justice Scalia's opinion simply ignored these contrary holdings. Surely the Court did not intend to overrule such an extensive line of cases without discussing the matter, especially since Justice Scalia hiniself had joined the Court opimions in Allied Tube and Trial Lawyers. ${ }^{93}$ But the Omni opinion leaves unexplained what exactly the grounds for distinction were.

\section{The Remaining Doctrinal Confusion}

The new trilogy of cases has helped settle some issues, but antitrust petitioning immunity renlains a doctrine without any clear noorings. It is more certain than ever that not all activities genuinely aimed at influencing the government receive immuinty for their direct effects. Walker

88. See infra text accompanying notes 256-76.

89. The California Motor Court's explanation for its holding, that improper petitioning activity is a sham, was overruled in Allied Tube. See supra text accompanying note 56. The holding itself, however, remained intact.

90. The opinion contains some loose language to support such an interpretation. It makes sweeping statements of immunity, e.g., Omni, $111 \mathrm{~S}$. Ct. at 1354 ("[F]ederal antitrust laws ... do not regulate the conduct of private individuais in seeking anticompetitive action from the government."), limited only by the statement that there is a sham use-of-process exception, id. at 1354-5.5.

91. In rejecting the conspiracy exception to state action immunity, the Court explicitly left open the possibility that the immunity might not apply when the government acted as a market participant. Id. at 1351, 1353. The Court did not explicitly leave open this market participant exception when it rejected the conspiracy exception to antitrust petitioning immunity. See id. at 1355-56. But since the explanation for the latter rejection simply incorporated the reasoning used for the former, id. at 1355 , presumably it also incorporated the limits of that reasoning and thus included the possibility of an exception where a petitioner conspires with a government acting as a market participant.

92. The holding in Trial Lawyers might be explained on the ground that the city government there was acting as a market participant, see supra note 91 , in purchasing legal services. This distinction is only significant, however, if the government conspires with the petitioner. In Trial Lawyers the city was coerced by the defendants, not in conspiracy with them.

93. Chief Justice Rehnquist and Justice Kennedy also joined all three Court opinions and Justice Blackmun joined both Allied Tube and Omni, as well as those portions of Trial Lawyers that interpreted Noerr, Allied Tube, and Claiborne Hardware. 
Process, California Motor, Allied Tube, and Trial Lawyers all denied immunity to activity that not only was genuinely intended to influence the government, but succeeded in doing so. But which such activities receive immunity and which do not? After decades of decisions, no clear rule has emerged.

The open-ended use of the sham and conspiracy exceptions to decide this question has correctly been rejected. But while the sourcecontext-nature test focuses attention on some relevant factors, it cannot provide doctrinal certainty as long as the Court is unable to make any definitive statement about which sources, contexts, and natures lead to immunity and which do not. The means-consequence and process-outcome tests also identify some relevant factors, but fail to articulate other factors that are necessary to explain the Court's case law.

The opinions also leave mixed messages about various more particular doctrinal questions. For example, should it matter whether the government is actimg as a market participant? Omni and Continental Ore suggest the answer may be "Yes." But Pennington granted immunity despite governmental participation in the market. And if market participation is not the measure of "commerciality," what is?

Where fraudulent means are used to obtain administrative or judicial action, should the petitioner be immune for the effects? Dicta in Allied Tube suggest the petitioner is immune for the effects of the governmental action, but not for any direct effects of such petitioning. Dicta in Omni suggest the petitioner is immune for both effects. Dicta in California Motor suggest the petitioner is not immune for either. And the only case to actually involve such a situation, Walker Process, held the petitioner liable for both effects, but did not discuss the issue.

When is a restraint incidental to petitioning efforts? This issue has never been explored by the Court. Perhaps the restraint must simply be coimected to the petitioning effort. Perhaps it must be necessary for the petitioning. Or maybe the restraint's effects must be small compared to the political effect. The opimions do not resolve the question.

Finally, what about mixed motive cases, where the process of petitioning is used both in hopes of obtaining governmental action and in order to impose expense and delay on competitors? Does any motive to impose costs and delay suffice to lose immunity? Or must the motive be significant or predominant? And how does one resolve either question?

This degree of uncertainty would be troubling for any doctrine. But it is deeply disturbing for a doctrine that purports to define the scope of the freedom to petition the government. 
II

\section{The Basic Structure of ANTitrust Process}

The doctrinal confusion that besets antitrust petitioning immunity has a source. It stems not from a lack of judicial skill in resolving the doctrinal gaps and ambiguities, but from the lack of any coherent explanation of the policies defining the scope of antitrust petitioning ininunity. Without some basic pohicy framework to guide resolution of doctrinal questions, it was entirely predictable that the doctrine would seen chaotic.

The Court has so far failed to provide this policy franiework. The Noerr Court did, to be sure, articulate the affirinative reasons for immunity: assuring governments the information necessary to govern, and assuring citizens the ability to communicate their views to the government. ${ }^{94}$ But the Court has never articulated a coherent policy justification for the limitations on this immunity.

Acadeniics have not done much better. They typically franie issues of antitrust petitioning imnuunity as accommodating a tension between First Amendnient freedonis and federal competition policy. ${ }^{95}$ This conceptual franiework obscures nore than it illummates. In cases of true conflict, fundamental constitutional principles require that any tension be resolved in favor of the First Amendnient. In cases beyond the scope of constitutional protection, any tension must be resolved in favor of the governing federal statute. ${ }^{96}$ In any event, explaining that issues must be adjudicated by accommodating a "tension" does nothing to structure doctrine, guide courts in adjudicating cases, or notify parties about how to conform their activities to the law.

To provide a niore useful policy franiework, I take an objective functional process approach. The aim is to chart, in lime with functional criteria, the types of decisionmaking processes producing restraints that do and do not receive immunity. The approach is process-oriented in

94. See Eastern R.R. Presidents Conference v. Noerr Motor Freight, 365 U.S. 127, 137-39 (1961).

95. See, e.g., Calkins, supra note 9, at 328; Hurwitz, supra note 10, at 66, 119; Ronald E. Kennedy, Political Boycotts, the Sherman Act, and the First Amendment: An Accommodation of Competing Interests, 55 S. CAL. L. REv. 983, 986, 1009, $1028-29$ (1982); Kintner \& Bauer, supra note 11 , at 552 .

96. Where the applicability of neither the Constitution nor a federal statute is clear, one canon of statutory construction counsels construing the statute to avoid constitutional questions. See Cass R. Sunstein, Interpreting Statutes in the Regulatory State, 103 HARV. L. REV. 405, 469 (1989). But this canon has been persuasively critiqued by others as an unjustified extension of the scope of constitutional limitations. See Henry J. Friendly, Benchmarks 210-12 (1967); RICHARD A. POSNER, THE FEDERAL COURTS 284-85 (1985). If the best, though not absolutely mandated, reading of a statute raises constitutional questions but ultimately is constitutional, construing the statute to avoid those questions will, without justification, deny the implementation of our best understanding of legislative policy. More persuasive is the canon that requires construing statutes to avoid only actual constitntional invalidity. 
that (like, I will show, the case law) it focuses on the nature and incentive structures of the decisionmaking processes producing the restraint and not on the substance of those restraints. The approach is objective in the sense that it focuses on objective indicia about the incentives of the participants in the decisionmaking process. It does not, as the doctrine does not, focus on the purity of the participants' subjective inotivations. From this process perspective, as we will see, much of the apparent tension disappears, and the more narrow conflict between the competitive and political processes can better be isolated and resolved.

Before beginning, a few words about nomenclature are appropriate. I describe the doctrine being analyzed simply as "antitrust petitioning immunity." I do not call it the Noerr doctrine or the Noerr-Pennington doctrine, because those designations misleadingly focus attention on cases that offer minimal guidance for the inore complex issues now facing the courts and that have, to a large extent, been transcended by the subsequent Supreme Court case law. Moreover, I use the term "antitrust immunity" quite generally to signify when the ordinary standards of antitrust review, which impose liability unless the proconipetitive effects outweigh the anticoinpetitive effects, ${ }^{97}$ are inoperative. The standards may be inoperative for reasons mside or outside of antitrust, and inside or outside antitrust's rule of reason. ${ }^{98}$

I thus intentionally do not specify whether the doctrine is an "exemption." Nor do I specify wliether it is an interpretation of the antitrust statutes or mandated by the First Amendment. Much ink lias been spilt debating these questions, ${ }^{99}$ and the Supreine Court's ambiguous statements on the issue have provided plenty of fodder for all sides in the debate. It is more fruitful, however, to focus not on the ambiguous dicta but on what practical import the answers have.

Here, the nuain implication drawn is that courts sliould narrow the

97. See, e.g., FTC v. Indiana Fed'n of Dentists, 476 U.S. 447, 459 (1986); National Soc'y of Professional Eng'rs v. United States, 435 U.S. 679, 688-96 (1978).

98. For example, the Suprene Court, while denying imnunity under the state action doctrine to municipal action unauthorized by the State, see Community Conmunications Co. v. City of Boulder, 455 U.S. 40 (1982), has suggested that special liability rules might apply to nunicipal action, see id. at 56 n.20. If such special liability rules were developed to preclude municipal liability for any restraints that had no effect outside municipal boundaries, then, in the sense I use the term, an "immunity" would apply to mumicipal restraints lacking extraterritorial effects.

99. For the argument that antitrust petitioning immunity is based on the First Amendment, see, e.g., Fischel, supra note 14, at 81-84, 94-104; Lawrence D. Bradley, Note, Noerr-Pennington Immunity from Antitrust Liability Under Chpper Exxpress v. Rocky Mountain Motor Tariff Bureau, Inc.: Replacing the Sham Exception with a Constitutional Analysis, 69 CORNELL L. REV. 1305 (1984). For the argument that it is siniply a matter of statutory interpretation, see, e.g., Handler \& De Sevo, supra note 35, at 4-5; Robert A. Zauzmer, Note, The Misapplication of the NoerrPennington Doctrine in Non-Antitrust Right to Petition Cases, 36 STAN. L. REv. 1243, 1251-53 (1984). For courts calling it an exemption to the Sherman Act, see Handler \& De Sevo, supra note 35 , at 5 n.16 (collecting cases). 
doctrine whether it is an exemption ${ }^{100}$ or co-extensive with the First Amendment. ${ }^{101}$ This is because exemptions are, by antitrust tradition, construed narrowly, ${ }^{102}$ and because the First Amendment provides limited protection against content-neutral regulations unless they unduly burden speech without leaving open alternative avenues of expression. ${ }^{103}$ These implications suggest answers, on a descriptive level, to the debated questions because there is plainly no operative tradition of construing antitrust petitioning immumity narrowly and the immunity in fact does extend beyond the himits of First Amendment protection. ${ }^{104}$

These imphications also suggest why the debated questions prove unhelpful on a normative level. Whether, as a matter of policy, the doctrine should be deemed an exemption depends on whether one believes it should be narrowly construed, and whether it should be deemed solely a First Amendment doctrime depends on whether one beheves it should extend beyond the limits of the First Amendment. Nothing is gained by addressing the debated questions in their abstract sense rather than proceeding directly to the substantive issues, and much may be lost if doctrinal issues are mishandled because attention from the substantive issues is diverted. It is to those substantive issues about decisionmaking processes that I now turn.

\section{A. The Core Elements: Defining Private and Public Decisionmaking}

A framework for analyzing the complex issues of antitrust petitioning immumity from a process perspective should begin with certain core elements: namely, decisionmaking processes that clearly are or are not within the scope of antitrust. I begin with the sort of decisionmaking process that produces the restraints ordinarily adjudicated in antitrust cases: restraints set by private businesses without any governmental involvement in their decision. Two businesses, for example, agree to boy-

100. See, e.g., Calkins, supra note 9, at 331-32.

101. See, e.g., Fischel, supra note 14, at 94-104, 122. Though beyond the scope of this Article, it should be noted that two other implications might follow if the doctrine were based in the First Amendment. First, such a basis might make the doctrine applicable to non-antitrust restrictions on petitioning activity. See Calkins, supra note 9, at 330-31 (collecting sources). See generally Zauzmer, supra note 99. Second, a First Amendment basis might render Noerr inapplicable to efforts to petition foreign governments. See Fischel, supra note 14, at 120-21; Kintner \& Bauer, supra note 11, at 564-65, nn.63-65 (collecting cases and commentary). See generally Douglas M. Ely, Note, The Noerr-Pennington Doctrine and the Petitioning of Foreign Governments, 84 CoLUM. L. REV. 1343 (1984).

102. E.g., Union Labor Life Ins. Co. v. Pireno, 458 U.S. 119, 126 (1982).

103. See LaURence H. TRIBE, American Constitutional Law $\S 12-2$, at 789-94 (2d ed. 1988). The First Amendment would also not protect deliberately deceptive petitioning. See Calkins, supra note 9, at 349-52.

104. See Handler \& De Sevo, supra note 35 , at $4 \mathrm{n} .14$; see also City of Columbia v. Omni Outdoor Advertising, $111 \mathrm{~S}$. Ct. 1344, 1353, 1356 (1991) (making clear that antitrust immunity applied even if the activities were illegal under other statutes and laws that would pass constitutional muster). 
cott another or to fix prices. Such a "private" decisionmaking process represents a classic case of non-immunity. There are questions about what the content of antitrust review should be in such cases, but no controversy about whether antitrust courts can review such restraints for substantive consistency with antitrust standards. ${ }^{105}$

At the other extreme is a restraint on competition set by the state. The state legislature, for example, might fix prices by making it illegal to sell milk below a minimum price or restrict entry by making it illegal to sell liquor without a license. Restraints produced by such a "public" decisionmaking process are immune from antitrust review under antitrust's state action doctrine. ${ }^{106}$ This is true even if the restraints are identical in substance to restraints that routinely receive antitrust scrutiny when the product of a private decisionmaking process. ${ }^{107}$

Of course, not all cases are as clear as our paradigmatic cases. In the ambiguous cases, the key question is how one determines whether the restraint resulted from public or private action. Like other doctrines relying on pubtic/private distinctions, ${ }^{108}$ the question has proved difficult to resolve by any purely formal criteria. ${ }^{109}$ But these formal difficulties do not mean, to use John Wiley's evocative phrase, "that no difference exists between . . . Congress and 535 strangers waiting for the bus." 110 Rather, we must identify the functional factors that, in each area of law, justify (and thus define) the distinction.

As I have argued elsewhere, the functional factors defining the scope of antitrust state action immunity conform to functional differences between different decisioninaking processes. ${ }^{111}$ Although it has not always made its reasoning clear, the Court has denied state action immumity (even if formal indicia of public action seem present) whenever a financially interested decisioninaker controls the terms of the imposed restraint. Conversely, the Court has found "state action," and thus conferred imınunity, whenever a financially disinterested and politically

105. Technically, the scope of federal antitrust law is also limited by the requirement that the restraint affect interstate commerce. But because the interstate commerce requirement is so weak, as a practical matter it excludes very few restraints. See Summit Health, Ltd. v. Pinhas, $111 \mathrm{~S}$. Ct. 1842 (1991); AREedA \& HovenKamp, supra note 10, I 232.1a, at 263-65; 1 Phillip AREedA \& DONALD F. TURNER, ANTITRUST LAw || 207, at 57 (1978). I will thus ignore the interstate commerce requirement, using the word "restraint" to refer to those restraints that have a sufficient impact on interstate commerce to provide federal jurisdiction.

106. See, e.g., Hoover v. Ronwin, 466 U.S. 558, 567-69 (1984).

107. See Fisher v. City of Berkeley, 475 U.S. 260, 266-67 (1986) (immunizing government rent control ordinance while noting that immunity would not apply to a private agreement to limit rents).

108. See generally Paul Brest, State Action and Liberal Theory: A Casenote on Flagg Brothers v. Brooks, 130 U. PA. L. Rev. 1296, 1302 n.21 (1982) (collecting sources); Morton J. Horwitz, The History of the Public/Private Distinction, 130 U. PA. L. REv. 1423, 1426 (1982) (same).

109. See Elhauge, supra note 25 , at $672-82$.

110. John S. Wiley Jr., A Capture Theory of Antitrust Federalism, 99 HARV. L. REV. 713, 773 (1986).

111. Elhauge, supra note 25 , at $682-96$. 
accountable ${ }^{12}$ actor has made a substantive decision in favor of the terms of the challenged restraint before it was imposed on the market. ${ }^{113}$ "Private decisionmaking" is thus merely a shorthand for financially interested decisionmaking, and "public decisionmaking" is a shorthand for decisionmaking that is financially disinterested and politically accountable. ${ }^{114}$

This distinction between state and private action is process-oriented because it turns on objective indicia about the incentives of the decisionmakers. It does not turn, as noted above, on the substance of the restraint. Nor does it turn on subjective motives. Bad motives will not deprive disinterested accountable decisionmakers of their antitrust inmunity. ${ }^{15}$ Good motives will not save financially interested decisionmakers froin antitrust review. ${ }^{116}$

One may begin to make sense of this antitrust definition of state action by asking why society allows financially interested producers the authority (enforced by state protection of property rights) to inake important resource allocation decisions for society. A major reason is that competitive markets provide a mechanism for harnessing that financial interest in the public interest because the process of competition causes producers to provide goods at the lowest cost to those who value

112. An actor is politically accountable in the special sense I mean if his or her authority can be traced to an election or some chain of appointment starting with elected officials. The accountability can be retrogressive rather than ongoing (it embraces judges with life tenure who were initially appointed by elected officials) and derivative rather than direct (it einbraces officials appointed by officials appointed by elected officials). See id. at $671 \mathrm{n} .10$.

113. Supreme Court cases subsequent to my article have continued to hew to the distinction I there described. See FTC v. Ticor Title Ins. Co., 112 S. Ct. 2169 (1992) (holding that no state action immunity applied where the disinterested state regulators made no substantive decision in favor of the challenged restraint on prices); City of Columbia v. Oinni Outdoor Advertising, 111 S. Ct. 1344 (1991) (holding that state action immunity applied where the restraint was a governmental restriction on billboards in which the government had no financial interest).

114. This abstracts from two related issues. The first is whether antitrust review applies to restraints imposed by financially disinterested but politically unaccountable actors. Such restraints present certain process problems, but such problems should probably not be policed under antitrust standards. See Elhauge, supra note 25, at 738-46. In any event, the applicability of antitrust to disinterested "private" restraints is not yet resolved. I shall have more to say about this issue below. See infra Section III.B.

Second, political accountability may itself create a financial interest when the restraint inposes anticompetitive effects outside the relevant jurisdiction. A state or city may restrain trade to exploit outsiders. With certain doctrinal complications, the review applicable to such restraints is broadly consistent with providing judicial review of financially interested restraints. See Elhauge, supra note 25, at 729-38. The dormant Commerce Clause provides judicial review of extraterritorial restraints by states, and the municipal action doctrine provides antitrust review of extraterritorial restraints by municipalities. But the municipal action doctrine is not yet settled. Most importantly, it is not yet clear whether special liability rules will effectively inmunize inunicipalities imposing restraints without extraterritorial effect. See id. at 732-38; see also supra note 98 (defining such special liability rules as an antitrust "inmunity" because they except the restraint from ordinary antitrust standards).

115. See Omni, 111 S. Ct. at 1352-53; Hoover v. Ronwin, 466 U.S. 558, 579-80 (1984).

116. See, e.g., NCAA v. Board of Regents, 468 U.S. 85, 101 n.23 (1984). 
them the most. Our assurance that producers' financially interested decisions will be in the public interest, in other words, rests on their being subjected to a competitive process. Federal antitrust review applies to make sure that their actions conform to this competitive process rather than undermine it to reap monopoly profits. Because antitrust is the fundamental guarantor that financially interested decisionmaking will, through the competitive process, advance the public welfare, no antitrust immunity can apply to decisionmaking by financially interested actors.

Why, then, do we allow governments to restrain free market competition? The answer is that the competitive process may be harmful when one takes account of market imperfections or noneconomic conceptions of the public good. Competitive markets are but one means of collectively allocating resources. ${ }^{117}$ There are others. We decide which means of collective resource allocation we will use-including how to define the market and when to deviate from it-through the government. Our assurance that the government will make sound decisions is provided by its accountability, political or procedural, to the affected parties. This political or procedural process is defined and policed by a host of legal doctrines, some constitutional in nature. Where governmental decisionmaking conforms to this process, and no financial interest is present, the functional concerns about the decisionmaking process are met and the rationale for antitrust review evaporates. ${ }^{118}$

In short, antitrust state action immunity helps serve to channel collective resource allocation decisions into either a competitive process (defined in large part by antitrust) or a political and procedural process (defined by bodies of law different from antitrust) that each provides some realistic assurance that the decisions will be in the public interest. We can represent the core elements of the decisionmaking processes that are and are not immune from antitrust scrutiny using simple diagrams. The decisionmaking process in the classic case of non-immunity is represented by Diagram $A$.

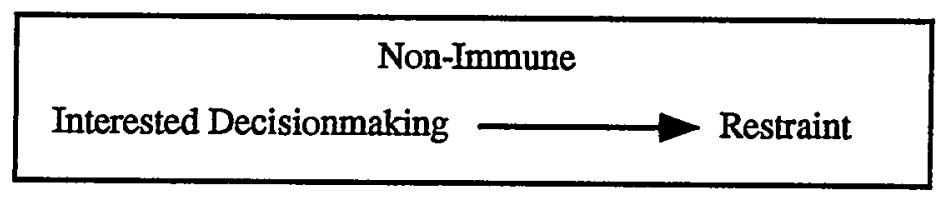

Diagram $A$

117. The resulting resource allocation is collective in the sense that the complex of legal doctrines that define and enforce market decisions (including antitrust, property, contract, tort, corporate, and criminal law) are established collectively.

118. See also Elhauge, supra note 25, at $697-708$ (collecting legislative history demonstrating that the Sherman Act was aimed at policing financially interested decisionmaking). 
The type of decisionmaking process receiving state action immunity is represented by Diagram $B$.

Immune
Disinterested Accountable Decisionmaking $\longrightarrow$ Restraint

Diagram B

This basic framework has implications for antitrust petitioning immunity. In particular, it helps us to decipher what the Allied Tube Conrt meant in declaring that antitrust petitioning immunity depends on "the source, context, and nature" of the challenged activity. ${ }^{119}$

\section{B. Basic Petitions for Public or Private Decisionmaking}

\section{Petitioning Disinterested Accountable Decisionmakers}

Consider, to begin with, the simple decisionmaking process represented by Diagram C: private, financially interested actors petition a financially disinterested governmental actor, through the normal means of the relevant political or procedural process, to restrain trade. For example, dairy farmers petition the state legislature to set mimimuin inilk prices. No restraint results directly from decisions by a financially

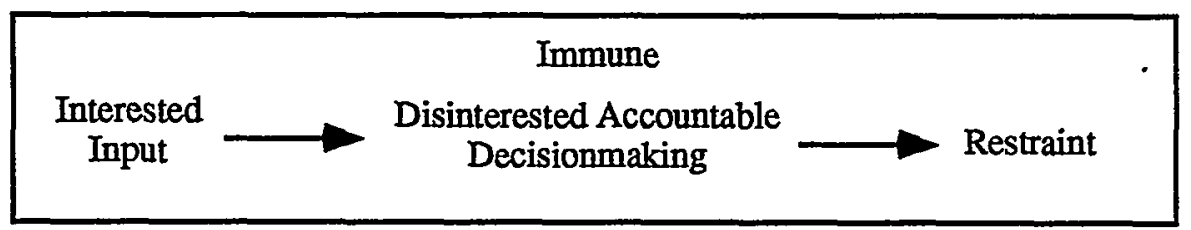

\section{Diagram $C$}

interested actor; rather the restraint is imposed only when a financially disinterested governmental actor decides in favor of the restraint. The restraint is accordingly immune under the state action doctrine. Because the decisionmaking process is thus sufficiently reliable to merit antitrust immunity, the petitioning that provided the input to that decisionmaking process should also be iminune. ${ }^{120}$ Petitioners' financial interest in the government's action is irrelevant because our assurance that the restraint furthers the public interest comes not froin the petitioners' decisionmaking process but from the government's. ${ }^{121}$

119. Allied Tube \& Conduit Corp. v. Indian Head, Inc., 486 U.S. 492, 499 (1988).

120. To this extent, antitrust petitioning immunity is derivative of state action immunity. But this is not always true. See infra Parts III-IV (explaining when petitioning immunity does not apply even though state action immunity may), Section V.A (arguing that petitioning immunity may apply in certain cases where government conduct is not immunized).

121. See Eastern R.R. Presidents Conference v. Noerr Motor Freight, 365 U.S. 127, 138-40 
Here, then, we have a case where the "source" of the restraint, the normal governmental decisionmaking process, renders the petitioning immune. In the Supreme Court case law, this paradigmatic case for antitrust petitioning immumity is illustrated by Pennington. There a union and various large coal operators sought to restrain trade to the detriment of competing small coal operators who paid lower wages. To achieve this restraint, they collectively petitioned the Secretary of Labor to set a minimum wage and petitioned the TVA to cease purchasing coal exempt from this minimum wage. ${ }^{122}$ Although the actions of the Secretary of Labor and TVA restricted competition by small coal operators, their actions would plainly receive state action immumity because such actions were the product of decisionınaking by financially disinterested and politically accountable government officials. The immunity of the petitioners was thus similarly clear, and the Court so held. ${ }^{123}$

Simce Pennington is the simplest and clearest case for petitioning immunity, it is not surprising that it contains the simplest and most sweeping language. Unfortunately, this language is all too often applied unthinkingly to cases involving much less pristine facts. The other Supreme Court cases, all of which involve complications absent in the Pennington opirion, express limitations on petitioning immunity which the Pennington Court had no occasion to explore.

\section{Petitioning Interested Decisionmakers}

Contrast decisionmaking process $\mathbf{C}$ with a case where the governmental actor is financially interested, as represented in Diagram D. In

$$
\begin{gathered}
\text { Non-Immune } \\
\text { Interested Input } \longrightarrow \text { Interested Decisionmaking } \longrightarrow \text { Restraint }
\end{gathered}
$$

Diagram D

that case the decisionmaking process producing the challenged restraint, while nominally public, is actually private within the ineaning of antitrust doctrine because the decisionmaker imposing the restraint is financially interested. The decisionmaker is considered a private actor not for any mystical reasons about the inherent nature of "state action," but because financially interested actors cannot be trusted to further the public interest unless subjected to a process of market competition policed by

(1961) (holding it irrelevant that petitioners sought governmental action because they hoped it would harm their competitors). This analysis applies not just when the petitioning influences the government to adopt a new restraint but also when it influences the government not to lift an old one. See id. at 130 .

122. United Mine Workers v. Pennington, 381 U.S. 657, 660-61 (1972).

123. See id. at 669-72. 
antitrust review. The "source" of the restraint being private action, no immunity applies.

Decisionmaking processes of type $\mathrm{D}$ are illustrated by Continental Ore. ${ }^{124}$ Although in that case the influenced entity was an official governmental agent exercising governmental authority, the Court denied immunity on the ground that the defendant's actions constituted "private commercial activity." 125 This language has misled some into concluding that there is no immunity for influencing the government to act in the market as a purchaser. ${ }^{126}$ But Pennington, which immunized efforts to influence the TVA's coal purchases, definitively establishes that antitrust petitioning immunity may apply to efforts to influence the government's actions as a inarket participant. ${ }^{127}$ Nor can the cases be distinguished on the ground that Pennington involved governmental purchases by a public official, because that was true in both cases. ${ }^{128}$

The true operative difference is that in Continental Ore the public official imposing the challenged restraint was financially interested in the anticoinpetitive consequences of that restraint, whereas im Pennington the public official was not. The official in Continental Ore was a subsidiary of a corporation that would benefit financially from having its competitors excluded fronı governnient purchases. ${ }^{129}$ Pennington, in contrast, involved the TVA, an entity with no financial interest in restricting competition between coal sellers. This difference in financial interest must be what the Supreme Court neans in labelling the official in Continental Ore "cominercial" but not the official in Pennington.

Whether or not it comports with ordinary understandings of what "commercial" means, it makes sense for the Court to focus on financial interest rather than on whether business activity is involved. The governmental/commercial distinction has never been workable. ${ }^{130}$ More importantly, governments can further the interests of their citizens in both market and non-market fashions. ${ }^{131} \mathrm{~A}$ government might, for

124. Continental Ore Co. v. Union Carbide \& Carbon Corp., 370 U.S. 690 (1962).

125. See id. at 707-08; see also supra text accompanying note 37.

126. See Hurwitz, supra note 10 , at $85-88$ (collecting sources).

127. Pennington would also seem to foreclose an exception for policy implementation, which some courts have recognized. See Kintner \& Bauer, supra note 11, at 563 n.56 (collecting cases).

128. See supra text accompanying notes $40-41$.

129. One might also conclude that, because the defendant controlled its subsidiary, the process was merely one of type A: a financially interested actor directly imposing a restraint. The process would not merit the immunity accorded process B, despite the defendant's governmental authority, because the decisionmaking process was financially interested. Consistent with this analysis, the Supreme Court not only denied antitrust petitioning immunity but state action immunity as well. Continental Ore, 370 U.S. at 706.07.

130. See Elhauge, supra note 25, at 682 n.66 (collecting sources showing unworkability of distinction in numerous legal fields).

131. See Gerald E. Frug, Property and Power, 1984 AM. B. Found. REs. J. 673, 687-90 (review essay) (suggesting that cities should operate banks, stores, housing units, and other typically private institutions). 
example, provide health care for its citizens either by running low-priced public hospitals or by imposing taxes to fund health care subsidies. There is no a priori reason to think that governments are better able to further the public interest by taxation and regulation than by market participation. Nor is there any reason to think that governments are more likely to mjure competition while running a business than through regulation. What justifies antitrust immunity is not the neans chosen but a disinterested and accountable decisionmaking process for choosing those means. As long as neither tlie government nor its officials has a financial interest in the governmental action, antitrust immunity should apply to botli the government and the petitioners. ${ }^{132}$

The above interpretation of Continental Ore and Pennington finds support in Allied Tube. The steel producers who infiuenced the standard-setting association in that case claimed inimunity in part on the ground that the association itself should be treated as a public body because its code was routinely adopted into law by state and local governments. ${ }^{133}$ Accordingly, the steel producers argued, their efforts deserved the same absolute immunity accorded those who persuade the government to restrain trade. The Supreine Court rejected this argument, reasoning that this immunity could not apply because "the decisionmaking body of the Association is composed, at least in part, of persons with economic mcentives to restrain trade."134 Further, the Court cited Continental Ore in support of its conclusion. ${ }^{135}$

The Allied Tube Court also noted that the association lacked official authority and was unaccountable to the public. ${ }^{136}$ But Continental Ore demonstrates that conferring "official" authority on financially interested actors does not render them public actors for the purpose of determining whether their restraints are immune from antitrust scrutiny. ${ }^{137}$ Continental Ore also demonstrates that accountability to disinterested higher officials will not immunize a restraint set by a financially interested actor: the actor there exercised authority delegated by the Office of Metals Controller, which retained both ultimate authority over the

132. The government does not have a financial interest in the sense meant here unless the governmental action exploits or threatens to create market power against outsiders. See Elhauge, supra note 25, at 729-38 (arguing for the same test of a government's financial interest for the purposes of adjudicating state action immunity).

133. The other part of their argument, which I described in Section I.B, relied not on the claim that the association itself was a public actor, but on the claim that influencing the association's code deserved immunity as an indirect effort to petition the state and local governments, which usually adopted its code into law. See supra text accompanying notes 60-61.

134. Allied Tube \& Conduit Corp. v. Indian Head, Inc., 486 U.S. 492, 501 (1988).

135. Id.

136. Id. at 501-02.

137. See supra notes 36-37, 124-29 and accompanying text; see also Elhauge, supra note 25, at 687-90 (arguing that Goldfarb v. Virginia State Bar, 421 U.S. 773 (1975), cited by Allied Tube, supports the same proposition). 
restraint being challenged and apparently the authority to remove the actor. ${ }^{138}$

In short, under the Supreme Court's case law, an actor's financial interest in a restraint that he or she controls seems sufficient to deprive the actor of state action immunity and to deprive those influencing the actor of the antitrust petitioning immumity accorded those who merely urge the government to restrain trade. Financial interest may not, however, be necessary to deprive an actor of state action immumity because the immunity may also not apply to disinterested but unaccountable actors who do not exercise official authority. ${ }^{139}$ Accordingly, accountability and official status may sometimes be relevant to immunity, which explains why Allied Tube mentions them as possible factors. But, financial interest will vitiate immunity regardless of whether accountability and official status are present.

\section{The Interest Group Theory Critique}

The Court's distinction between financially interested decisionmaking and interested input into a disinterested accountable decisionmaking process has recently come under fire because of interest group theory. Interest group theory concludes that small intense groups will make more political effort, and thus have more political influence, than will large diffuse groups because the latter face greater collective action problems. ${ }^{140}$ The members of a large diffuse group have little incentive to make political efforts for the group because each member gains a small share of the group benefits from political victory and knows that the member's own individual efforts would have little impact on the chances of victory. Because they gain a larger share of group benefits and have more proportional impact on the chances of political victory, members of small groups are more likely to independently or interdependently contribute toward political efforts. Moreover, smaller groups have an easier time organizing collective agreements to overcome the incentive of members to free ride on the political effort of other members.

Based on this interest group theory, some scholars have recently argued that antitrust petitioning immunity should be narrowed to curb interest group influence that distorts or corrupts governmental decisionmaking. ${ }^{141}$ Interest group theory, these scholars argue, overthrows the

138. See Continental Ore Co. v. Union Carbide \& Carbon Corp., 370 U.S. 690, 702 n.11 (1962); see also Elhauge, supra note 25, at 712-17 (arguing that public accountability does not and should not immunize a restraint controlled by a financially interested actor).

139. See Elhauge, supra note 25 , at 738-46.

140. For a more thorough explanation of interest group theory, see Einer R. Elhauge, Does Interest Group Theory Justify More Intrusive Judicial Review?, 101 YALE L.J. 31, 35-44 (1991).

141. See Minda, supra note 24; see also Wiley, supra note 110, at 739-76, 779-81 (arguing for antitrust invalidation of inefficient governmental restraints resulting from petitioning that constitutes interest group capture of the government, but not for imposing damages on the petitioners). 
presumption that a disinterested accountable governmental actor represents all the affected parties. Instead, government actors are often disproportionately influenced by special interest groups, and in those cases governmental actions deserve no more immunity than those interest groups would receive if they restrained trade themselves.

Interest group theory cannot, however, justify this constriction of petitioning immurity. ${ }^{142}$ The principal conceptual problem is that interest group theory cannot determine whether an interest group's political influence is distorting or disproportionate without some normative baseline to determine how much influence the interest group should have. ${ }^{143}$ Public choice theory generally presumes that interest group influence is disproportionate when it exceeds the group's economic interest in a regulation. ${ }^{144}$ But this baseline assumes that the group with the largest economic interest should wim, which is the same as saying that governmental action should comport with the normative standard of economic efficiency-wealth maximization. ${ }^{145}$ Nothing in antitrust law justifies imposing this standard, or any other normative standard, on all governmental decisionmaking. ${ }^{146}$

In dismissing the related argument that there should be an immunity exception when petitioning has "corrupted" the governmental process into acting against "the public interest,"147 the Omni Court indicated that it understood this conceptual problem and explicitly rejected economic efficiency as a normative baseline imposable on the political process through antitrust review. The Court stated:

The fact is that virtually all regulation benefits some segments of the society and harms others; and that it is not universally considered contrary to the public good if the net economic loss to the losers exceeds the net economic gain to the winners.... [D]etermination of "the public inter-

Professor Minda also argues that corrupting, unethical, or deceptive methods of petitioning should be denied immunity. Minda, supra note 24, at 1011-24. But this argument does not truly rest on interest group theory because that theory predicts interest groups will be more effective at utilizing whatever methods of influencing the government are open to them. See Elhauge, supra note 140, at 49. For further discussion of Minda's argument for using antitrust to police improper methods of political petitioning, see infra Section IV.C.1.

142. The following discussion summarizes arguments I have made elsewhere. See Elhauge, supra note 140.

143. See id. at 48-66. The theory also shows that capture is incomplete: politically accountable decisionmaking may overrepresent special interest groups, but it will also give some representation to less politically powerful groups. See id. at 42-43. Thus, even if interest group theory narrows the difference between governmental and financially interested decisionmaking, it does not eliminate it. Disinterested accountable decisionmaking on restraints affecting special interest groups will not have the same bias as restraints directly adopted by those interest groups. Some distinetion is thus warranted.

144. See id. at $52-53$.

145. See id. at 53-55.

146. There are also more particular indications that Congress never intended the Sherman Act to be used to root out interest group capture. See Elhauge, supra note 25, at 722.

147. City of Columbia v. Omni Outdoor Advertising, 111 S. Ct. 1344, 1352-53, 1355 (1991). 
est" in the manifold areas of government regulation entails not merely economic and mathematical analysis but value judgment . . ${ }^{148}$

The second problem in using interest group theory to justify constricted petitioning immunity is that expanding antitrust review of governmental decisionmaking would, in effect, substitute the litigation process of decisionmaking for other governmental processes, even though interest group theory gives us no reason to think the litigation process is preferable. ${ }^{149}$ Just as petitioning for legislative and executive action creates collective action problems because the action can confer benefits (or costs) on group members regardless of whether the niembers contribute to seeking (or opposing) the action, so too judicial precedent confers benefits (and costs) on groups regardless of individual members' contributions. Interest group theory thus predicts that sniall intense groups will have greater incentives than large diffuse groups to expend resources on frequent hitigation, skillful counsel, strategic settlenient, and influencing judicial appointments. ${ }^{150}$ This should give small intense groups more infiuence over the hitigation process.

To the extent judges' general political insulation protects thein from this interest group influence, ${ }^{151}$ litigation decisionmaking reflects judicial views unknown, unappreciated, or as yet undeveloped at the tine of appointment. There is no reason to think this random collection of personal views will better reflect the will of the people than a pohtical process allegedly distorted by interest group influence. ${ }^{152}$ "Judges may be less biased, but dice are unbiased too." 153

Again Omni seemed to recognize the problem, and it rejected the

148. Id. at 1353. Although this reasoning was used to reject an exception to state action immunity, it was incorporated into the rationale for rejecting an equivalent exception to petitioning immunity. See id. at 1355-56.

149. See Elhauge, supra note 140 , at $66-83$.

150. See id. at 68-83. Class actions are an imperfect response to this problem because they cannot solve the problem of who represents the large diffuse group in choosing and guiding its class action representative. See id. at 72-76.

151. It cannot completely insulate the litigation process because interest groups can, through the above strategies, influence the litigation process even if they do not alter the opinions of any judges. See id. at 80 .

152. See id. at 83-87. Other related arguments are (1) that more intrusive antitrust review would at least raise the transaction costs of interest group capture, and (2) that, because of Arrow's theorem and collective choice theory, judicial decisionmaking is more rational than political decisionmaking. The first argument fails because more intrusive antitrust review might lower the transaction costs of interest group capture (as when antitrust courts strike down legislation in a way that helps interest groups) and because increasing transaction costs can perversely encourage interest group activity by making capture more costly to undo, increase the relative advantage of interest groups because they are better able to meet higher transaction costs, and freeze into place a legal status quo that benefits interest groups. See id. at 34-35, 87-101. The second argument fails because the process defects identified by collective choice theory are normatively dubious and equally applicable to judicial review or to any status quo that is left in place by making legal change more difficult. See id. at 101-09.

153. Elhauge, supra note 25 , at 725 . 
shift in decisionmaking power. An exception for governments "corrupted" by petitioners into acting contrary to the public interest must be rejected, the Court declared, because the exception is so malleable that it would shift decisionmaking power over basic value judgments "from elected officials to judges and juries."154

Accordingly, Omni immunized an established billboard conipany that persuaded the City Council, which it had long supported politically, to adopt zoning restrictions on new billboard construction that effectively excluded a new entrant, even though the restriction arguably reflected interest group pressure and was surely economically inefficient. This holding, coupled with Omni's reasoning, establishes an intportant doctrinal conclusion: namely, that whether or not one agrees with my conclusion that interest group theory does not justify more narrow antitrust imnunity, the theory does not describe the current contours of antitrust petitioning immunity. ${ }^{155}$

\section{III}

Using Market Coercion to Influence Public DECISIONMAKING

\section{A. Coercive Processes}

Consider next the decisionmaking process presented when a financially interested private actor uses a restraint of trade as a means of influencing the government. For example, suppose doctors boycott a public clinic to stop it from using chiropractors to provide medical services. We might illustrate the situation with Diagram E. Here the terms of the

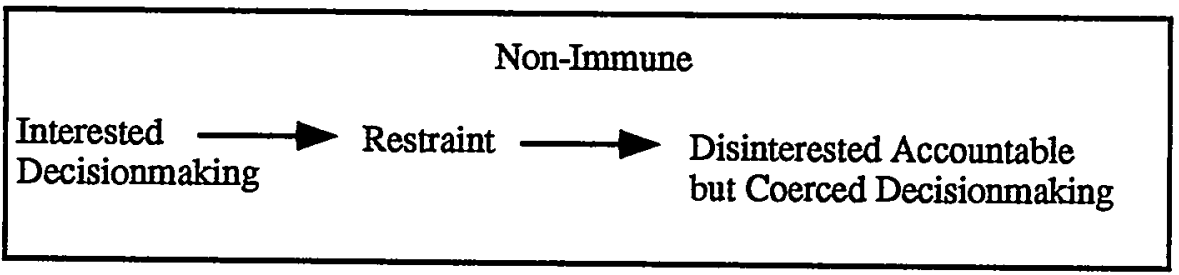

Diagram $E$

restraint are set by a financially interested decisionmaker, and no financially disinterested and publicly accountable actor made a substantive decision in favor of the restraint before it was imposed. Moreover, the influence of the restraint on the public decision relies, at least in part, on market coercion.

Because the decisionmaking process producing the restraint cannot

154. City of Columbia v. Omni Outdoor Advertising, 111 S. Ct. 1344, 1352 (1991).

155. Interest group theory also does not describe the contours of state action immunity case law. See Elhauge, supra note 25 , at 720-21. 
be trusted to operate correctly without antitrust scrutiny, and because the coercive nature of the restraint undermines rather than furthers the reliability of the decisionmaking process producing the governmental action, no immunity should apply to the restraint resulting from private decisionmaking. The nature of the activity intended to influence governmental action-a coercive privately set restraint-makes immumity inapplicable. ${ }^{156}$

The foregoing is true whether or not the government action itself produces a restraint. Nor is it relevant whether the government is being coerced as a market participant or as a regulator. A financially imterested restraint that coerces governmental action is equally problematic whether the government responds to the coercion by regulating or by changing the terms at which it buys and sells. And where there is no such coercion, the governmental action is just as likely to advance the public interest whether regulatory or proprietary. ${ }^{157}$

An interesting question would, however, appear to be raised as to whether a restraint resulting from governmental action should receive state action immunity when the government action is disinterested but coerced by a private restraint that is not immune. This issue has not yet been resolved, but, as I argue elsewhere, ${ }^{158}$ it seems that state action immunity should not apply to this governmental restraint because the coercion eliminates any assurance that the decisionmaking process was likely to further the public interest. Damages, however, would not and should not be available against the government in such a case. ${ }^{159}$

156. See FTC v. Superior Court Trial Lawyers Ass'n, 493 U.S. 411, 421-25 (1990); United States v. North Dakota Hosp. Ass'n, 640 F. Supp. 1028, 1040-43 (D.N.D. 1986) (concerted activity directed at the governnient as a consunier in the niarketplace held not imnune); Michigan State Medical Soc'y, 101 F.T.C. 191, 204-07, 314 (1983) (same). Other forms of coercing governnient officials, such as threats of violence, are also not entitled to antitrust inınunity. See Sacraniento Coca-Cola Bottling Co. v. Chauffeurs Local 150, 440 F.2d 1096, 1099 (9th Cir.), cert. denied, 404 U.S. 826 (1971).

157. See supra text accompanying notes 130-32. Other authors have argued that boycotts of the government should receive ininunity when the governnient is purchasing and has nionopsony power. See Hurwitz, supra note 10, at 112; Mitchell D. Raup, Medicaid Boycotts by Health Care Providers: $A$ Noerr-Pennington Defense, 69 IowA L. REv. 1393, 1396-97, 1414-15 (1984). But this argunient fails on two scores. First, it has never been an accepted antitrust defense that a restraint of trade is necessary to countervail the nuarket power of a monopsonistic private party. See PhILliP AREedA \& Louis KAPlow, ANTitruST ANAlysis 195 \& n.24, 223 n.46 (4th ed. 1988). Second, the government has nuany nionopolies, most iniportantly a monopoly on regulatory authority, and there is no reason why those groups that happen to have the economic power to exercise coercive influence should have an advantage over less powerful citizens in influencing the government's exercise of its nonopoly powers. In any event, the argument seems legally untenable after Trial Lawyers, since there the city was effectively a nonopsonistic purchaser of legal services for indigent criminal defendants in the District of Colunibia. See Trial Lawyers, 493 U.S. 411.

158. See Elhauge, supra note 25, at 704 .

159. See id. at 735,736 n.322. 


\section{B. Objective Financial Interest}

Trial Lawyers ${ }^{160}$ illustrates decisionmaking process $\mathrm{E}$ and clarifies the focus on the objective financial interest of the defendants. The trial lawyers' collective refusal to represent indigent criminal defendants was, without doubt, genuinely intended to obtain government action: an increase in fees. But from an objective process perspective, the boycott was also coercive and financially interested. The subjective motivation behind the boycott may have been, as the trial lawyers claimed, their desire to make sure fees were high enough that indigent criminal defendants would receive effective representation. And the substantive result may have been to improve legal representation for indigent defendants and vindicate their Sixth Amendment rights. But the Court determined that neither the subjective motive nor the substantive merit of the restraint was relevant. ${ }^{161}$ What mattered was that the trial lawyers had an objective financial interest in receiving higher fees. This rendered the decisionmaking process producing the challenged restraint the sort that must be subjected to a competitive process policed by antitrust ground rules.

The Court's refusal to use a subjective motive test to determine the applicability of antitrnst immunity is sound. Such inquiries serve neither plaintiffs nor defendants. Allegations of a bad motive can always be made and are hard to dismiss on summary judgment. Moreover, it is difficult to determine what happens in a person's heart of hearts, and easy for that person to control evidence about it, skewing in his favor the mix of information that is presented. ${ }^{162}$

The probleins with a subjective motive test, however, go beyond its unworkability. The graver problen is that judicial bias will infect immunity decisions. While persons do not always act based on their financial interests, they often do. Judicial decisions about whether particular defendants were subjectively motivated by their financial interest will likely reflect judicial biases that some groups are better than others in rising above their financial interests: for example, that professionals can put aside self-interest but non-professionals cannot; or that unions are public-spirited but management is not. Because subjective motive tests

160. 493 U.S. 411 (1990).

161. Id. at $421-24,427 \&$ n. 11 .

162. See Stephen McG. Bundy \& Einer R. Elhauge, Do Lawyers Improve the Adversary System? A General Theory of Litigation Advice and Its Regulation, 79 CALIF. L. REv. 313, 323-26, 335-61 (1991); Louis Kaplow \& Steven Shavell, Legal Advice About Information to Present in Litigation: Its Effects and Social Desirability, 102 HARv. L. REv. 567, $577-82$ (1989); see also Ronald J. Gilson, The Devolution of the Legal Profession: A Demand Side Perspective, 49 MD. L. REv. 869, 881-82 (1990) (factfinding process biased toward underinclusion of relevant information). Courts can make adjustments for this skew, as they have done by making bad-motive allegations hard to dismiss. See Bundy \& Elhauge, supra, at 383-91, 393. In general, though, adjudication will be more accurate if the information relevant to adjudication is available to both parties. See id. at 381-82, 392-93. 
lend themselves to such judicial biases, they are not only a hindrance to antitrust enforcement but offensive to First Amendment principles. They threaten to create judicially imposed content-based discrimination, ${ }^{163}$ and thus chill desirable forms of speech. Far better for courts to apply evenhandedly the same presumption about susceptibility to financial interest to all actors.

Where objectively the defendants have no financial interest at issue, private efforts to use restraints as a means of influencing governmental action stand in a different light. Because the competitive process relies on the financial interest of competitors driving thein toward producing the right set of goods using the right inputs, one cannot say that using antitrust review to impose a competitive process on financially disinterested decisionmaking will lead to better results. True, the unaccountability of dismterested private decisionmakers raises the concern that their actions will be arbitrary, vindictive, overzealous, or in furtherance of an idiosyncratic view of the public interest. But it may be better to police such financially disinterested action with legal tools better suited for the task than antitrust review. ${ }^{164}$

To soine extent such financially disinterested restraints are immunized under Claiborne Hardware. ${ }^{165}$ There the Court held that the First Amendinent immunized a consumer boycott of white inerchants designed to force the merchants to end racial discrimination both in their businesses and in their roles as government leaders. The key factor, the Court stressed in Trial Lawyers, was that the Claiborne Hardware boycotters (unhike the Trial Lawyers boycotters) did not " 'stand to profit financially froin a lessening of coinpetition in the boycotted market." "166 The Court also inentioned that the Claiborne Hardware boycotters sought to vindicate constitutional rights. ${ }^{167}$ But while such a constitutional objective inay be necessary to confer inmunity on a disinterested restraint, it is plain after Trial Lawyers that benign subjective inotivations, whether or not they involve the vindication of constitutional rights, are not sufficient to confer immunity on a financially interested restraint

163. Cf. City of Lakewood v. Plain Dealer Publishing Co., 486 U.S. 750, 760-62, 769-72 (1988) (holding it unconstitutional to entrust city officials with unbridled discretion over speech regulation because of the risk of content discrimination).

164. See Elhauge, supra note 25, at 738-46. The legislators who enacted the Sherman Act discussed only one financially disinterested non-public restraint, a temperance society boycott of liquor retailers, and all agreed the Sherman Act should not cover it. See 21 CoNG. REC. 2658-59 (1890) (statement of Sen. Sherman); 20 CoNG. REC. 1458-60 (1889) (statements of Sens. George, Sherman, and Stewart).

165. NAACP v. Claiborne Hardware Co., 458 U.S. 886 (1982).

166. Trial Lawyers, 493 U.S. at 427 (quoting Allied Tube \& Conduit Corp. v. Indian Head, Inc., 486 U.S. 492 , 508 (1988)); see also Claiborne Hardware, 458 U.S. at 915 (stressing same factor).

167. Trial Lawyers, 493 U.S. at 426; see also Allied Tube \& Conduit Corp. v. Indian Head, Inc., 486 U.S. 492, 508 (1988). 
used to seek governmental action. ${ }^{168}$

This helps resolve what some ${ }^{169}$ have regarded as an anomalous tension between Noerr and Pennington, which in conferring immunity emphasized the irrelevance of a defendant's financial motivation in seeking governmental action, ${ }^{170}$ and Allied Tube and Trial Lawyers, which in denying immunity emphasized that the defendants were financially interested. ${ }^{171}$ The latter cases are concerned about the objective incentives of the persons imposing the restraint on trade being challenged. Where those incentives create a financial interest in restraining trade, a competitive process of decisionmaking is required, and antitrust inmunity cannot apply even if the defendants offer to prove that their subjective motivation was good. Where, however, the challenged restraint is imposed by persons without financial incentives and with accountability to the public, then the coinpetitive process is inapt, and the political process is adequate even if those seeking the governinental action have financial incentives and motives. In either sort of case, the operative factor is whether the objective incentives of those making the ultimate decisions provide soine realistic assurance that the decisions will further the public interest. ${ }^{172}$ Subjective inotivations-whether those of financially interested restrainers or petitioners for restraints-are irrelevant under the Court's objective process approach.

The process approach also explains why, if Noerr sounds in the First Amendment, its scope should differ so inuch from that of Claiborne Hardware, which unlike Noerr offers protection only to financially disinterested actors. Noerr provides immunity to input, financially interested or disinterested, into a disinterested accountable decisionmaking process because it is the decision of the latter that provides the assurance that any resulting restraint is in the public interest. Where the restraint precedes and is indeed aimed at coercing governmental action, however, such assurances of reliability do not exist. Noerr imınunity thus does not apply, and the First Ainendment protection that does apply is justifiably limited, given the greater danger posed by such restraints, to those

168. See Trial Lawyers, 493 U.S. at 424, 427 \& n.11; Allied Tube, 486 U.S. at 498 (denying immunity even though the defendants seeking governmental action "acted, at least in part, based on a genuine belief that plastic conduit was unsafe"); infra text accompanying notes 285-92 (discussing immunity for political boycotts that do not coercc the government).

169. See, e.g., Allied Tube, 486 U.S. at 512-13 (White, J., dissenting).

170. See United Mine Workers v. Pennington, 381 U.S. 657, 670 (1965); Eastern R.R. Presidents Conference v. Noerr Motor Freight, 365 U.S. 127, 138-40 (1961).

171. See Trial Lawyers, 493 U.S. at 427; Allied Tube, 486 U.S. at 508-09.

172. Or, to put the matter more precisely, the issuc is whether the objective incentives are sufficiently reliable that the decisionmaking process is unlikely to be improved by subjecting it to antitrust review. See supra text accompanying notes 140-55 (arguing that, even if distorted by interest group influence, disinterested accountable decisionmaking is unlikely to be improved by substituting a litigation process of decisionmaking); see also supra text accompanying note 164 (arguing that financially disinterested but publicly unaccountable decisionmaking may not be improved by being subjected to antitrust review). 
imposed by financially disinterested parties. ${ }^{173}$

\section{The Market Power Defense}

Another issue addressed by Trial Lawyers was whether to recognize a lack-of-market-power defense. The dissenters felt that symbolic boycotts should receive First Amendment protection from antitrust hability unless market power is proven. ${ }^{174}$ The Court disagreed. ${ }^{175}$ The oddity of this dispute was that the record contained clear evidence of anticompetitive effect: severe shortages of lawyers willing to take indigent defendants. ${ }^{176}$ Such proof of actual anticompetitive effect should have obviated any need for proof of market power, which is only one means of inferring anticompetitive effect. ${ }^{177}$

In any event, the Court dispensed with proof of market power for

173. Further limits might also be justified. See Elhauge, supra note 25 , at 744-45 (suggesting that the First Amendment protection might also be limited to cases where the disinterested restraint penalized an alleged constitutional violation and where the government had not already determined the legal penalties to apply to the violation); Michael C. Harper, The Consumer's Emerging Right to Boycott: NAACP v. Claibome Hardware and Its Implications for American Labor Law, 93 YALE L.J. 409, 426-32 (1984) (arguing for limiting the Claiborne Hardware right to consumer boycotts designed to induce social decisions that are legal).

174. Trial Lawyers, 493 U.S. at 436-53 (Brennan, J., concurring in part and dissenting in part); id. at 453-54 (Blackmun, J., concurring in part and dissenting in part).

175. 493 U.S. at 428-36. This holding negated any implication that references to "market power" in Allied Tube, 486 U.S. at 507, required economic market power to deny immunity. The Allied Tube Court's references to market power apparently meant only that the defendants were directly exercising the power to stop association members' purchases of certain goods or services (in other words, that market behavior was involved).

176. Before the boycott, there was no shortage of lawyers willing to take indigent defendants at the governmental rate. Trial Lawyers, 493 U.S. at 415 . With the boycott, $90 \%$ of the lawyers who usually took indigent defendants refused to accept new assignments. Id. at 416 . The few lawyers taking indigent defendants were swamped, and key figures in the city's criminal justice system " "became convinced that the system was on the brink of collapse." Id. at 418.

177. See FTC v. Indiana Fed'n of Dentists, 476 U.S. 447, $460-61$ (1986); 7 PHILlip E. AREedA, ANTITRUST LAW If 1511, at 429 (1986). Justice Blackmun's dissenting opinion mistakenly concluded that the trial lawyers had no market power because the city had the power to order lawyers to represent indigent defendants on a pro bono basis. See Trial Lawyers, 493 U.S. at 453-54 (Blackmun, J., dissenting). However, such orders are not perfectly enforceable, and compulsion would not have produced the same product if unwilling lawyers provide worse representation than willing ones. Moreover, coercing lawyers to represent indigent clients has substantial political costs. That the administrative problems, quality concerns, and political costs of compelling legal services made the government willing to pay the financial costs of the trial lawyers' price-fixing scheme does not deprive the government of the right to a competitive price for contracted legal services. Alternatives, or substitutes, often exist for goods. People can, for example, always drink beer instead of wine. But the availability of beer does not mean that purchasers are not entitled to competition among wine producers. Like beer to wine, so too compelled legal services are an imperfect substitute for contracted legal services.

The implications of Justice Blackmun's position are even more disturbing once one considers that the government just about always has the power to intervene in a market to set rates and allocate supply. If market power does not exist whenever the government could rectify the results of an anticompetitive combination through regulation, then the Sherman Act would be a dead letter. Cf. Elhauge, supra note 25, at 712-17 (explaining why antitrust state action immunity applies only if the government approves a private restraint before it is imposed on the market). 
the usual set of practical reasons. Per se violations pose a serious danger to competition unbalanced by any plausible procompetitive virtue, and inquiring into whether the defendants had the inarket power to make their restraint effective would complicate adjudication, raise litigation costs, and lessen deterrence. ${ }^{178}$

Trial Lawyers thus appropriately established that lack of market power would not confer immunity on financially interested restraints that, if they had market power, would coerce governmental action. But the market power defense should still apply if the issue is whether the defendant should be liable in damages for any restraint imposed by the coerced government. ${ }^{179}$ Unless market power actually existed, there is no real coercion and no reason to doubt the reliability of the government's decision to impose its own restraint. Further, as we will see, proof of market power is also necessary to impose antitrust liability for the costs directly imposed on coinpetitors by the process of litigating. ${ }^{180}$

\section{IV \\ Private Action that Both Restrains Trade aND PROVIDES NONCOERCIVE INPUT TO GOVERNMENTAL DECISIONMAKING}

We come next to a more complicated scenario. Sometimes the conduct of private, financially interested actors has dual effects that coincide with each other. One effect nuay be to influence government action without any coercion but through the normal course of the political or procedural process used to reach governmental decisions. Another effect may be to directly restrain niarket competition whether or not the government makes a substantive decision in favor of the restraint. We may represent such cases with Diagram F.

178. See Trial Lawyers, 493 U.S. at $432-34 \&$ n.16. Justice Brennan's dissent concluded that the boycott's message persuaded city residents to become sympathetic to the lawyers, see id. at 442,445 (Brennan, J., dissenting), but it is more likely that the lawyer shortages produced sympathy for the indigent defendants. As long as there was no shortage, the "plight" of lawyers voluntarily earning $\$ 20 /$ hour was probably not moving to most city residents, most of whom earn far less. The dissent also emphasized that, before the boycott, many legal groups and government officials supported the fee increase, and no one spoke against it. See id. at 442-43. But this is hardly surprising. Interest group theory predicts that those with concentrated interests will be more successful in organizing testimony than those with diffuse interests. See Elhauge, supra note 140, at 35-39; cf. James L. Payne, The Congressional Brainwashing Machine, PUBL1C INTEREST, Summer 1990, at 3, 4 (out of a sample of 1060 witnesses before Congress, only 7 opposed spending, 39 were neutral, and 1014 favored it). That the City Council, despite the influence of concentrated interests, refused to enact a pay raise out of fear taxpayers would vote against the councilmembers in subsequent elections is arguably a triumph of the political process, not a malfunction of it.

179. See supra text aceompanying notes 158-59.

180. See infra text accompanying notes 254-55. 


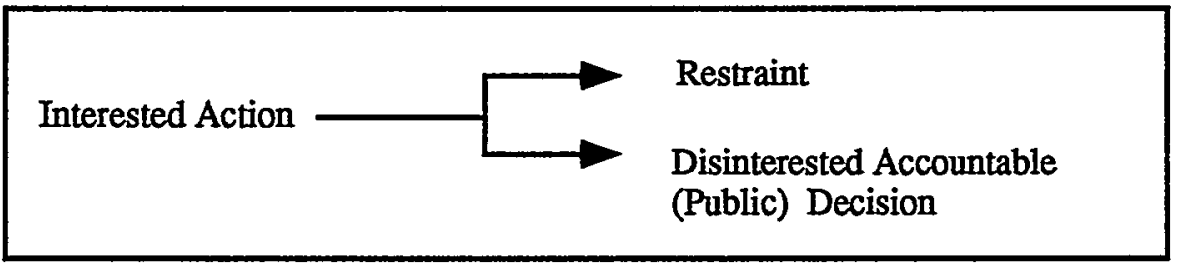

\section{Diagram $F$}

Three Supreme Court cases illustrate the problems posed when a Diagram F scenario results in antitrust litigation. The first is Noerr itself, where the railroad's publicity campaign both (1) fostered governmental decisionmaking that restrained trucker competition, and (2) directly restrained trade by interfering with trucker-customer relations. ${ }^{181}$ The second is California Motor, where the defendants' strategy of automatically litigating to stop their competitors from getting licenses both (1) often succeeded in liaving their competitors demed licenses and (2) directly imposed delays and costs on their competitors that discouraged their entry into the market. ${ }^{182}$ The third is Allied Tube, where the steel producers' infiuence on the standard-setting association both (1) resulted in governmental codes that legally restrained their competitors from selling plastic conduit, and (2) directly restrained trade because the associational standard (a) constituted an implicit agreement among association members not to buy or sell plastic conduit, and (b) discouraged nonmembers from insuring or purchasing plastic conduit. ${ }^{183}$

There is no legal difficulty as to the first type of effect: when the process leading to a restraint is disinterested and accountable, immuinty applies. The difficult issue, which arises whether or not the influenced public decision restrains trade, is how to treat the second effect: the restraint resulting directly from financially interested decisionmaking. Here a potential conflict arises between the competitive process, which is fostered by judicial antitrust review of restramts produced by private decisionmaking, and the functioning of governmental processes, which are fostered by private input that would be deterred by antitrust review and penalties.

The response of the Supreme Court case law to the potential process conflict posed in such situations is quite nuanced. Unfortunately, these nuances can often be obscured because, in adjudicating interested private restraints that coincide with disinterested governmental action, courts often erroneously apply the sweeping langnage used by Noerr and

181. See supra notes $26-28$ and accompanying text.

182. See supra notes $45-47$ and accompanying text.

183. Allied Tube \& Conduit Corp. v. Indian Head, Inc., 486 U.S. 492, 495-96, $498-99$ \& n.2, 500,507 (1988). The latter effects directly restrained competition by plastic conduit manufacturers in all the jurisdictions that did not prohibit the use of plastic conduit. 
Pennington to describe the immunity accorded to restraints produced by disinterested governmental decisionmaking. By the same token, the relam tively sweeping nature of petitioning immunity for restraints produced by disinterested (and uncoerced) governmental decisionmaking is sometimes obscured because courts mistakenly apply the nuanced review that the Court intended to apply only to interested restraints that coincide with disinterested governmental action. It is thus worth emphasizing that the following analysis applies not to restraints resulting from disinterested governmental decisionmaking but only to restraints resulting from financially interested action that also provides mput into governmental decisionmaking.

\section{A. The Sham Limitation}

The Court grapples with the potential process conflicts raised by such restramts mainly through a series of tests that effectively establish whether a real process conflict exists. The first is the sham limitation. ${ }^{184}$ Sometimes parties attempt to claim immunity when the alleged input into public decisionmaking is a "sham" in the sense it is not actually designed to influence the governmental decision. In such cases, represented in Diagrain G, there is no real conflict between the decisionmaking processes because the private action provides no real input into the process of governmental decisionmaking.

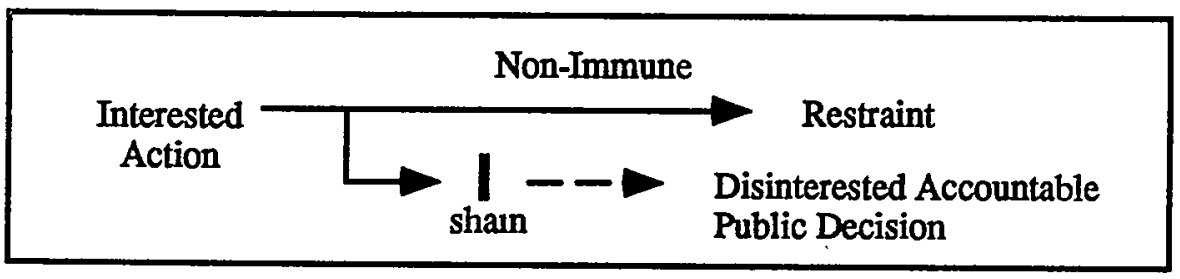

Diagram $G$

Indeed, once one recognizes the sham, the decisionmaking process in such cases reduces to the paradigmatic process represented by Diagram A. Because immunity for the restraints directly resulting from sham petitioning is not needed to further the process of governmental decisionmaking, it should, as the Court has stated, be denied. ${ }^{185}$ Although this is often called the sham "exception," it is more accurate to term it a limitation because it marks not an exception to the immunity for efforts to influence officials but a definition of when the immunity

184. Some courts have misapplied this limitation to restraints that result from or coerce governmental decisionmaking, but it is truly applicable only to restraints that coincide with alleged input into such decisionmaking.

185. City of Columbia v. Omni Outdoor Advertising, 111 S. Ct. 1344, 1354 (1991); Allied Tube, 486 U.S. at 500 n.4, 508 n.10; Eastern R.R. Presidents Conference v. Noerr Motor Freight, 365 U.S. 127, 144 (1961). 
does not, by its own terms, apply because no such effort is actually being made.

This should, of course, be distmguished from the so-called sham exception once used to police "improper" petitioning. ${ }^{186}$ True shams are rare, particularly in the legislative context. Petitioners almost always genuinely desire government action, and seldom have no possibility of getting it. Otherwise the petitioning, particularly in a political forum, would usually not tie up the antitrust plaintiff enough to inflict injury.

Where there is no sham, the restraint resulting directly from private action is immune under Allied Tube only if "it is 'incidental' to a valid effort to influence governmental action."187 This raises two questions whose answers are illuminated by the objective process approach. First, how can courts determine whether a restraint is "mcidental" to an effort to influence the government? Second, if the restraint is deemed mcidental, how can courts determine whether the effort to influence the governinent was "valid"?

\section{B. Incidental v. Nonincidental Restraints}

The Court has not yet spelled out the contours of the requirement that restramts be "incidental" to petitioning. At a minimum, however, the incidental standard must mean that the defendant cannot claim immumity for restraints resulting from activities that were in fact separate froin the valid effort to influence the government. ${ }^{188}$ In other words, petitioning immumity does not cast a protective cloak over activities that did not contribute to (i.e., were separate from) the petitioning effort.

Allied Tube is illustrative. There the plaintiff alleged that the defendants did not stop at influencing the private electrical code widely adopted by state and local governments but also engaged in concerted efforts to "market" (directly to potential purchasers) the stigma that the plaintiff's product suffered froin code exclusion. This marketing effort was likely to influence purchasers, but made no apparent contribution to the defendants' efforts to influence goverument decisionmakers. The Court accordingly suggested that the marketing effort might "alter the incidental status of the resulting anticompetitive harm," but did not reach the issue since it denied immunity on other grounds. ${ }^{189}$

A more common example of nomincidental restraints would be allegations that competitors jointly petitioning for governmental restrictions have, in the course of agreeing about what restrictions to ask the govern-

186. See supra text accompanying notes 5-6, 9, 49-52.

187. Allied Tube, 486 U.S. at 499 (quoting Noerr, 365 U.S. at 143).

188. See Noerr, 365 U.S. at 143 (concluding that the restraint was "incidental" to the publicity cainpaign because the direct anticompetitive injury complained of was an "inevitable" effect of the campaign).

189. Allied Tube, 486 U.S. at 503 n.8. 
ment to provide, also agreed to adopt those restrictions themselves irrespective of government action. Milk producers, for example, might use discussions about petitioning for governmental milk price supports to agree on a cartel price that they will charge pending governmental action and/or if the government declines to adopt the proposed milk price support. Although such activity might be painted as a Diagram F case, in fact the agreement to impose the cartel price is separate from the petition, and thus the case is more accurately represented by Diagram $\mathrm{H}$.

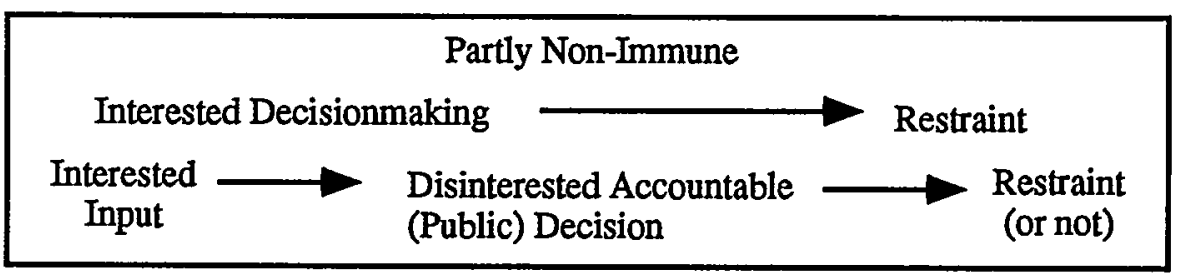

Diagram $H$

In other words, the restramts in fact result from two separate decisioninaking processes. Any restraint resulting from the dismterested accountable (public) decision is just like that described in Diagrain $\mathbf{C}$ and should be immunized. But the parallel agreement set by the interested decisioninaker is separate from the petitioning effort and just like that described in Diagram A. It is thus not mcidental to the effort to influence governmental action and should receive no antitrust immunity. ${ }^{190}$

This reasoning might seem belied by the fact that firms are commonly allowed to agree jomtly on the rates they submit to governmental regulators. But if the government regulator already fixes the prices that can be charged, then any "parallel" agreement on prices can have no anticompetitive effect. In Southern Motor Carriers, ${ }^{191}$ for example, the Court held that the state action doctrine immunized collective rate proposals authorized by a state commission. Such immumity is superficially mconsistent with the process standards put forth in this Article since those collectively making the rate proposals were financially interested. But, as the Court emphasized, the disinterested state commission was

190. Accord Clipper Exxpress v. Rocky Mountain Motor Tariff Bureau, 690 F.2d 1240, 1263-65 (9th Cir. 1982), cert. denied, 459 U.S. 1227 (1983); AREEDA \& HovenKAMP, supra note 10, ๆ $206.1 \mathrm{~b}$, at 82.83 (collecting cases). Immunity also does not and should not apply where a monopolist injplements an exclusionary practice pending regulatory approval. See Litton Sys. v. American Tel. \& Tel., 700 F.2d 785, $807-08$ (2d Cir. 1983), cert. denied, 464 U.S. 1073 (1984); Kintner \& Bauer, supra note 11, at $581 \mathrm{n} .127$ (collecting cases). Nor does it or should it apply after regulatory approval if that approval is not substantive. See FTC v. Ticor Title Ins. Co., 112 S. Ct. 2169, 2177 (1992); Cantor v. Detroit Edison Co., 428 U.S. 579, 601-02 (1976) (plurality opinion), overruled on other grounds by California Retail Liquor Dealers Ass'n v. Midcal Aluninum, 445 U.S. 97 (1980).

191. Southern Motor Carriers Rate Conference v. United States, 471 U.S. 48 (1985). 
responsible for setting all rates. ${ }^{192}$ Any implicit private agreement on rates could thus have no effect without governmental approval. Nor could it have a coercive effect since the commission was not a purchaser but a rate-setter. The case thus involved the process protections normally present when a disinterested accountable actor makes a substantive decision in favor of the terms of the challenged restraint. Where the disinterested regulators have not made a substantive decision in favor of the rates before they are imposed on the market, these process protections are not present, and, as the Court recently made clear in Ticor Title, ${ }^{193}$ antitrust immunity does not apply.

Similarly, to the extent rates are unregulated, we should condemn a parallel agreement on price that takes effect before or without substantive governmental approval. ${ }^{194}$ One might think it would be impossible in such a case for a court to disaggregate the agreement on price charging from the agreement on rate proposals. ${ }^{195}$ But petitioning the government to restrict prices would have no purpose if those prices could prevail in a freely competitive market. Thus, if the requested price support became the price charged in the market either before the government acted or after the government refused to intervene, then courts can presume an agreement on price charging was in fact reached. Since an agreement on price charging does not contribute to the petition for price supports, it can fairly be separated out from those petitioning activities.

The position here, that separate parallel restraints are not incidental and thus not immune, should be distinguished from the position that there is a preliminary discussion exception to petitioning immunity. ${ }^{196}$ Such a preliminary discussion exception would deny immunity when the defendants are not petitioning but are preparing to petition. The exception was adopted and advocated with the aim of denying immunity to the sort of restraints that can be denied immunity under the separability test I have just described. But the preliminary discussion exception was overbroad. It would, for example, deny inmunity to letters soliciting donations for a lobbying group or to meetings where private groups decide on the content of their petition, because such activities are preliminary to petitioning.

From a functional process perspective, it does not matter whether

192. See id. at $65-66$.

193. FTC v. Ticor Title Ins. Co., 112 S. Ct. 2169 (1992); see Elhauge, supra note 25, at 695-96 \& n.145 (stressing that the disinterested governmental actor must make some substantive decision in favor of the challenged restraint, though the merits of any substantive decision that is made should be beyond antitrust scrutiny).

194. This could be the situation even in a regime of governmental rate regulation if the parallel private agreement set prices higher than a governmental floor on rates.

195. Cf. Hurwitz, supra note 10 , at 90 (describing distinction drawn by the cases as uncertain).

196. For discussions by scholars taking the latter position, see, e.g., Hurwitz, supra note 10, at 88-90; Kintner \& Bauer, supra note 11, at 568, 579-80. See also Calkins, supra note 9, at 345 n.92 (collecting sources). 
the activity is preliminary to, concurrent with, or even subsequently to the petitioning that directly reaches government officials. The key question is whether it was functionally separate from the petitioning (and any governmental restraint) so that antitrust review can apply without fear of chilling input into the governmental decisionmaking process. Because preliminary discussions are generally integral to petitioning, such input would be severely chilled by a preliminary discussion exception. Moreover, the beneficial aspects of the exception can be provided instead by reading the incidental test to exclude separate parallel restraints. In line with this analysis, the preliminary discussion exception now seems foreclosed by Allied Tube. ${ }^{197}$

Similarly, the position here should be distinguished from the position, urged by some commentators, that immunity should be denied if the party could have petitioned in an alternative manner that would have caused less direct anticompetitive harm. ${ }^{198}$ The question under the separability test is not whether the parties could have separated the challenged activity from their petitioning efforts; rather, it is whether the courts, looking at the complex of activities claimed to be immune, can separate out some because they did not contribute to the petitioning effort. In a sense, the separability test is simply an extension of the sham limitation. Just as activities do not receive immunity when the entire petitioning effort was a sham not genuinely designed to influence the government, so too activities do not receive immunity when, even though some legitimate petitioning occurred, the alleged connection between the particular activities and the legitimate petitioning is a sham because those activities made no genuine contribution to the petitioning efforts.

A least restrictive alternative test of whether the activity is incidental to the petitioning should be rejected because it would embroil courts in the sort of case-by-case evaluation of petitioning that a functional process approach aims to avoid. A range of petitioning methods that can influence the government will generally exist. Which petitioning method causes the least direct injury is a matter of fine judgment that would require close scrutiny in each case. Worse, it seems likely that whatever method a defendant chooses, a court will always be able to find some less injurious alternative.

Moreover, the method causing the very least direct injury will often

197. See Allied Tube \& Conduit Corp. v. Indian Head, Inc., 486 U.S. 492, 503 (1988) (rejecting claim that indirect petitioning may not be immunized).

198. See, e.g., 1 AREEDA \& TURNER, supra note 105, I 201, at 37 (arguing that antitrust immunity should not apply to "behavior that is 'unnecessarily harmful' to competition in the sense of being excessively dangerous without being indispensable to the political activity"); 1 id. $\Uparrow 205$, at 51-52 (same); David L. Meyer, Note, A Standard for Tailoring Noerr-Pennington Immunity More Closely to the First Amendment Mandate, 95 YALE L.J. 832, 838-41 (1986); see also Allied Tube, 486 U.S. at 498 (noting that the trial court had the jury determine whether the defendant's actions were "the least restrictive means" of expressing the defendant's opposition to the use of plastic conduit). 
be one that has little chance of political success. Tlius, unless antitrust review is to relegate petitioners to politically ineffective means of petitioning, courts applying the least restrictive alternative test must, explicitly or inplicitly, balance the value to petitioners of using politically effective means of petitioning against the harm to competition. ${ }^{199}$ But courts have no administrable standards for weighing political effectiveness and anticompetitive injury. Such open-ended balancing would leave petitioning clilled by the uncertain risk of treble damages. More troubling, because judges will likely deem petitioning for the political causes they support more valuable, such balancing will skew immumity toward petitions that correspond to the political views judges happen to hold.

Accordingly, the limitation of immunity to incidental effects appropriately does not require that the defendant alter his choice among valid petitionimg strategies. It requires only that the defendant not claim immunity for restraints or anticompetitive effects that flow from activities separate from the valid petitioning method chosen. The First Amendment, it is true, does not require the government to leave open the most effective means of cominunication if adequate alternatives are available. ${ }^{200}$ But antitrust allows petitioners to cloose the most effective means among the ones the government has left open.

\section{The Validity of the Petitioning}

The Court determmes the "validity" of private petitioning efforts, and thus the apphicability of antitrust petitioning immunity to the restraints that are incidental to (and directly result from) such efforts, by examining "the context and nature" of the efforts. ${ }^{201}$ This should not be misconstrned as a general warrant for courts to reacli their own normative judgments about the fairness of the petitioning effort. That would be inconsistent with the doctrine's process-oriented framework. Rather, the Court in effect uses this test to determine whether the process conflict is so severe that the competitive process (and the antitrust review that ensures it) should yield to the process for providing input to governnental decisions.

Where the effort would be invalid within the prevailing standards of the process providing input to governmental decisionmaking, there is no real conflict between the two processes. The situation is represented by Diagram I. Antitrust scrutiny would not hamper the process of providing input to governmental decisionmakers because the input is, by the standards of the process at issue, invalid. Serious concerus about the

199. See 1 AREedA \& TURNER, supra note 105, 1 205, at 52 (concluding that courts must weigh "(i) the severity of the danger to competition, (ii) the obviousness of a less dangerous alternative, and (iii) the customary political character of the challenged behavior").

200. See Meyer, supra note 198 , at 840 n.40 (collecting cases).

201. Allied Tube, 486 U.S. at 499. 
governmental process : are thus not at issue. ${ }^{202}$ In contrast, antitrust immunity would hinder the competitive process because the decision to impose the restraint is financially imterested. Accordingly, immunity should not (and does not) apply to the restraint that directly results from the interested action.

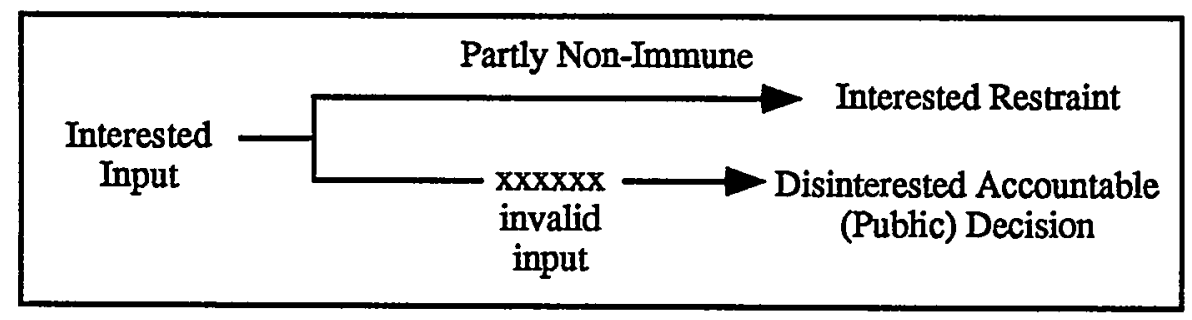

\section{Diagram I}

This does not mean, however, that imvalid petitioning would vitiate immumity for any restraint that resulted from the dismterested accountable decisionmaking process. Invalidity only removes the shield of immumity over the restraint that directly resulted from the financially interested action. Where the restraint at issue resulted from the public (disinterested, accountable) process, then the grounds for antitrust review do not apply at all, even if that public decision is based on invalid input. Accordingly, the Court has stated, a petitioner's violation of state or federal law does not, standing alone, deprive the petitioner (or the government) of antitrust immumity for such a public restraint. ${ }^{203}$

Violatimg the standards apphicable to the governmental process does, however, deprive the petitioner of immumity for the restraints that directly result from his actions. To be sure, this does not mean that antitrust liability necessarily applies. Unless the direct effects are anticompetitive and the invalid petitioner is financially interested, the competitive

202. Professors Areeda \& Turner agree to the extent that they concede applying antitrust sanctions to conduct that has already been legally proscribed does not "deprive the government of anything useful," "chill permissible behavior," or "intrude upon legislative functions." 1 AREEDA \&

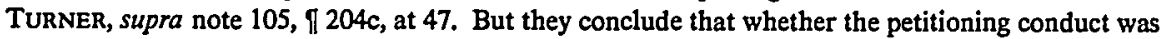
already legally proscribed will generally be irrelevant because governmental action will be the supervening cause of the anticompetitive injury. See 1 id. $\$ 204 d$, at $49-50$. They also argue that inquiries into whether the illegal petitioning "caused" the governmental action are too fraught with difficulty to allow. See $1 \mathrm{id}$. The Court in Omni adopted these arguments in dicta. See City of Columbia v. Oinni Outdoor Advertising, 111 S. Ct. 1344, 1353 (1991). These points have force, but they do not apply to the issue at hand, which is whether the independent illegality of the petitioning should deprive the petitioner of antitrust inmunity for the injury that directly results from the petitioning activity. I shall have more to say about whether bribing and misleading government officials should render the petitioner liable for governmental actions below. See infra Part V.

203. See Omni, 111 S. Ct. at 1353; see also Allied Tube, 486 U.S. at 499 (where the restraint results from “'valid governmental action, as opposed to private action,' those urging the governmental action enjoy absolute inınunity") (quoting Eastern R.R. Presidents Conference v. Noerr Motor Freight, 365 U.S. 127, 136 (1961)). 
process and antitrust review need not apply. The ordinary penalties for violating the laws that make the petitioning invalid should suffice. But invalidity should remove the immunity that would otherwise apply to financially interested restraints.

Many commentators have taken issue with such a conclusion, arguing that, because numerous other laws regulate and punish invalid petitioning, there is no reason for antitrust to add "extra" penalties. They argue that it would be "irrationally piecerneal" to use the Sherman Act to police invalid petitioming because the evils of such petitioning are not limited to efforts to achieve anticoinpetitive ends. ${ }^{204}$ Either the other laws regulating petitioning adequately deter abuses, in which case antitrust review is unnecessary, or they provide inadequate deterrence, in which case more systemic changes are required.

This argument is wrong on two scores. First, the deterrence critique iguores a distinguishing feature of anticompetitive activity: it can be enormously profitable. Because of this, the legal penalties that, in the ordinary case, suffice to deter abusive petitioning may be imsufficient to deter abusive petitioning that achieves anticonipetitive results.

The second and more fundanental reason is that all financially interested restraints raise the process concern that merits antitrust review. Financially interested restranits caused directly by parties seeking governmental action are no exception. The issue is not whether the antitrust laws should impose "additional" penalties but whether, given the existence of a restraint imposed by a financially interested process, the ordinarily applicable antitrust review should be set aside because the restraint is incidental to mput into the governmental process. Where the conduct is invalid even within the rules of the governmental process, there is no reason for antitrust to defer.

The Court's test of invalidity given the nature and context of the conduct should not be confused with the position it has correctly rejected: that the shain exception should be used to deny immunity when petitioning is deenred "iinproper." The problenı with the improper nreans test was that it invited antitrust judges to make ad hoc judgments about what sorts of behavior they thought proper. Under the Court's present test, judges look at whether the conduct violates the legal standards already prevailing in that context. This helps assure that decisions coniport with the functional process ideals underlying the doctrine. It also restrains courts froin iniposing their own substantive values and provides some meaningful guidance to persons seeking to coinply with the law.

Where the effort to influence the government is valid under the pro-

204. See Calkins, supra note 9, at 344 n.87; Note, Application of the Sherman Act to Attempts to Influence Government Action, 81 HARv. L. REv. 847, 850-51 (1968); see also Sullivan, supra note 10, at 362 (arguing that it is wrong to use antitrust to police impropriety). 
cess standards applicable given the context of the effort, but also has direct anticompetitive consequences, it raises a real conflict between policing the competitive process and fostering input into governmental processes. The situation is represented by Diagram J. The activity

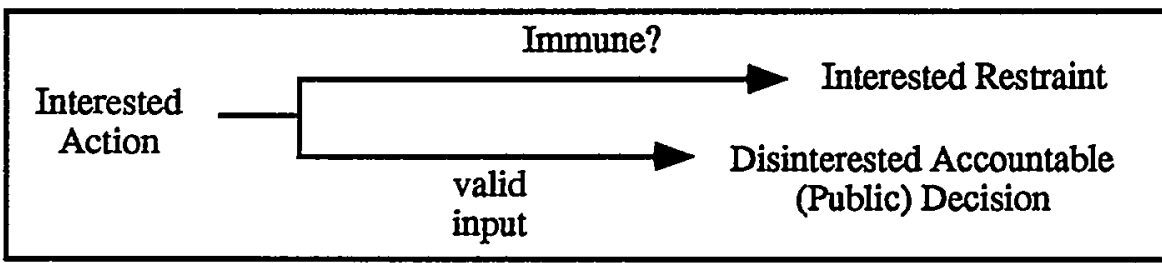

\section{Diagram J}

producing the direct restraint is financially imterested and would thus benefit from being channeled, by antitrust review, into a coinpetitive process. But the same activity also provides valid input into the governmental process that would be deterred witlout antitrust iminunity.

Some line has to be drawn im such cases of actual process conflict. The line effectively drawn by the Supreme Court turns on whether the interested action involves market behavior, such as collective agreeinents on price, output, or boycotts. ${ }^{205}$ The coinpetitive process defers to the need for input into the governmental process (and antitrust immunity apphies) when the interested action does not involve such market behavior. The competitive process does not defer (and antitrnst immunity does not apply) when the interested action does involve market behavior.

This line seems fairly sensible. Where the defendants have reached some collective agreement on their market conduct, antitrust concerns about the competitive process are paramount because such agreements directly interfere with free competition. Concerns about the governmental process are less important because any infornational input provided by collective market behavior (such as the views expressed by a symbolic boycott or a product.standard) can instead be provided through verbal communication. 206

205. In first providing antitrust petitioning immunity, the Noerr Court stressed that the activity at issue there bore

very little if any resemblance to the combinations normally held violative of the Sherman

Act, combinations ordinarily characterized by an express or implied agreement or understanding that the participants will jointly give up their trade freedom, or help one another to take away the trade freedom of others through the use of such devices as pricefixing agreements, boycotts, market-division agreements, and other similar arrangements. Eastern R.R. Presidents Conference v. Noerr Motor Freight, 365 U.S. 127, 136 (1961). Allied Tube cited this passage and echoed its sentiment in denying immunity to market behavior that provided input to the government. See Allied Tube, 486 U.S. at 507, 509-10 (stressing that the association comprised market participants whose behavior would be affected by the product standard); see also id. at 503-04 (citimg various types of market behavior that could not receive antitrust petitioning immunity); FTC v. Superior Court Trial Lawyers Ass'n, 493 U.S. 411, 425 (1990) (same).

206. See Trial Lawyers, 493 U.S. at 426 (emphasizing that although immunity did not protect 
On the other hand, where the defendants' conduct impinges on coinpetition only because it disparages a competitor's goods or requires the competitor to endure the costs and delays of opposing the defendants' petitioning, antitrust concerns (while undemably present) are less critical. The central nervous system of the market-competition over prices, output, and quality-is not directly hampered. In contrast, concerns about the governmental process are critical because reputational harms and the costs and delays imposed by opposition are inevitable whenever citizens petition their government for action.

To summarize, direct private restraints that are not separable from genuine petitioning are immune if the petitioning conforms to the norms applicable in the relevant process context and does not involve inarket behavior. The following explores the various contexts in which the Court has elaborated this doctrime.

\section{Validity in the Political Process}

Antitrust immurity has always been at its broadest in the pohtical process. Noerr immunized a publicity campaign that used a deceptive tactic: circulating materials imder the names of seemingly independent third parties to inask the fact that the railroads were behind the antitrucking campaign. Although the Court felt such activity was unethical, it nonetheless immunized the campaign from antitrust scrutiny because it did not involve inarket behavior ${ }^{207}$ and was valid under the standards applicable to the political process. ${ }^{208}$ The third-party technique was "in widespread use" and apparently was not prohibited by the laws then applicable to lobbying. ${ }^{209}$

Many commentators lave critiqued Noerr, and antitrust petitioning immunity in general, for protecting political tactics that are deceptive, unethical, or corrupting. ${ }^{210}$ It inay be true, these commentators argue, that we expect less lionest or ethical behavior in the political arena than in litigation, but are our expectations really so low and, if so, why should antitrust be governed by these expectations? ${ }^{211}$ The threat of antitrust liability may deter deceptive and unethical political conduct, but that

the boycott itself it did protect "the association's efforts to publicize the boycott, to explain the merits of its cause, and to lobby District officials to enact favorable legislation"); Allied Tube, 486 U.S. at 507 (stressing that the non-immune defendant "did not confine itself to efforts to persuade an independent decisionmaker; rather, it organized and orchestrated the actual exercise of the Association's decisionmaking authority") (citation omitted); id. at 510 (noting that the defendant was free to engage in "direct lobbying, publicity campaigns," or "presenting and vigorously arguing accurate scientific evidence"); Noerr, 365 U.S. at 138-39 (describing the immune conduct as "mere solicitation").

207. Noerr, 365 U.S. at 136-37.

208. Id. at $140-41 \&$ n. 20 .

209. Id.

210. See, e.g., Calkins, supra note 9, at 348-52; Minda, supra note 24, at 911, 914-24, 1014-15.

211. See Calkins, supra note 9 , at 348 \& $n .113,352$. 
hardly seems a social loss. Noerr, these commentators point out, had two main justifications: the government's need to obtain the informational input necessary to govern, and the right of citizens to inform the government of their wishes. ${ }^{212}$ But the government's ability to govern is not improved by obtaining deceptive information. ${ }^{213}$ And the right of citizens to petition does not include the right to spread falsehoods. ${ }^{214}$

The reason for providing immunity to allegedly deceptive or unethical political conduct is obviously not that such lobbying is desirable. Nor does the reason rest on the naive behef that others will correct any false information; that is, that the inarketplace of ideas is a perfect one. ${ }^{215}$ For we know that some voices in the inarketplace of ideas win out not because their messages are true but because they are inore ainplified. ${ }^{216}$ And everyone would agree that deceptive and unethical tactics, even if often correctable by a vigilant opposition, are unlikely to further affirmatively the pursuit of truth.

The reason for immunity is the conviction that having antitrust courts police unethical or deceptive pohitical petitioning would be worse than the problem. To begin with, such antitrust review inight chill desirable speech. For example, the Court in Noerr condemned the tactic of petitioming under the names of third parties as falling "far short of the ethical standards generally approved in this country."217 But such third party techniques can and have been used by groups to avoid persecution for voicing unpopular ideas. ${ }^{218}$ Allowing antitrust courts to penalize third party techniques may thus deter unpopular speakers from adding their input into the process.

Judicial review of the veracity of political statements would be even more chilling. Many pohitical statements depend on controversial assertions about social facts: for exainple, that hicensing either is or is not necessary to protect public safety, that increasing taxes either will or will not seriously discourage production, and that environmental regulation imposes either high or low economic costs. Allowing antitrust courts to mipose treble damages on those political statenients that judges and

212. See Noerr, 365 U.S. at $137-39$.

213. See Fischel, supra note 14, at 100-01; Minda, supra note 24, at 1013.

214. See McDonald v. Smith, 472 U.S. 479, 484 (1985). For commentators arguing or suggesting that, because of this, intentionally false petitioning should not receive antitrust immunity, see Calkins, supra note 9, at 349-52; Fischel, supra note 14, at 100-04; Hurwitz, supra note 10, at 8384.

215. See generally Abrams v. United States, 250 U.S. 616, 630 (1919) (Holmes, J., dissenting) (" $[T]$ he best test of truth is the power of the thought to get itself accepted in the competition of the market ...."); JOHN S. Mill, ON LIBERTY 75-118 (Gertrude Himmelfarb ed., Penguin Books 1985) (1859).

216. See, e.g., Mark Tushnet, Red, White, and Blue: A Critical ANalysis of CONSTITUTIONAL LAW 283 (1988) (arguing that some voices "drown out" others).

217. Eastern R.R. Presidents Conference v. Noerr Motor Freight, 365 U.S. 127, 140 (1961).

218. Cf. TRIBE, supra note 103, § 12-26, at 1019-20 (collecting First Amendment cases that invalidated laws requiring organizations to disclose the identity of their members). 
juries find deceptive would discourage citizens from offering mput about the likely effects of economic regulation.

Some have argued, relying by analogy on the commercial speech cases, that we should be less concerned about chilling effects where petitioning is economically motivated. ${ }^{219}$ An initial problem with this argument is that judicial mquiry into whether the subjective motive for petitioning was econonic or political would itself chill speech and give judges power to favor some petitioning over others. ${ }^{220}$

But even if stricter antitrust review is himited to cases where parties have an objective financial interest in the political outcome, the chill will likely remain significant because of free rider problems. Although a group of petitioners, say, for example, physicians, miglit reap a net financial benefit from petitioning for anticompetitive but arguably desirable regulation, sucli as setting higlier standards for licensing future physicians, individual petitioners might lack the necessary incentive to petition. The reason is that, acting individually, each bears tle full costs of lier own petitioning but must sliare the financial benefits of anticompetitive regulation (higher fees) with otliers. ${ }^{221}$ Each thus has a financial incentive to free ride off of whatever political effort the others exert. Petitioning groups can offset this structural incentive to free ride only tlirougli collective agreenents and social sanctions, ${ }^{222}$ both of which would be undermined by the threat of legal penalties, let alone treble damages.

The analogy to commercial speecli is accordingly inapt. Coininercial speech faces no corresponding free rider problems. The speaker generally reaps all the financial gains from her advertising and can weigli those gains against the risk of legal penalties. ${ }^{223}$ The risk of legal penalties causes less of a chill because it runs counter to the speaker's financial incentives ratlier tlian, as with a petitioner for political action, in line witli thein. ${ }^{224}$

More dangerous than the clilling effect, an open-ended power to

219. See Minda, supra note 24, at 1008 n.375; Natalie Abrams, Note, The Sham Exception to the Noerr-Pennington Doctrine: A Commercial Speech Interpretation, 49 BRook. L. REV. 573, 594 (1983); Meyer, supra note 198, at 852.

220. See supra text accompanying notes 162-63.

221. For a fuller explanation of free riding problems and collected sources, see Elhauge, supra note 140 , at $36-37$.

222. Some commentators have doubted that the individual right to petition justifies an immunity for combinations among petitioners. See 1 AREEdA \& TURNER, supra note 105, I 204b, at 46; Kintner \& Bauer, supra note 11, at 553. The analysis in the text should dispel these donbts. If concerted petitioning did not enjoy antitrust immnnity, free riding problems would make petitioning infeasible for all bnt petitioners who individually garner a very large share of the benefits of favorable governmental action.

223. See Posadas de Puerto Rico Assocs. v. Tourism Co., 478 U.S. 328, 340 (1986) (defining commercial speech as speech that proposes no more than a commercial transaction).

224. See generally Calkins, supra note 9, at 350 n.124 (colleeting authorities concluding that economically motivated petitioning is not commercial speech). 
review the ethics or accuracy of political petitioning might be used by antitrust courts to take sides in political debates. Indeed, the case history of Noerr itself amply demonstrates this danger: the trial court had held the railroads liable but not the truckers even though both sides conducted publicity campaigns that used the same third party techniques. ${ }^{225}$ Similar dangers would be posed by judicial review of deception. Imagine, for example, claims and counterclaims by landlords and tenants alleging that the other lied by asserting that rent control is (or is not) socially efficient. Most economists may well agree with the landlords, but it is far better to have the veracity of such statements determined by the political process than by unelected judges and juries.

These problems with judicial review of petitioning do not apply powerfully when the question is whether antitrust immunity should apply to conduct that is already illegal under prevailing regnlatory standards. One need not have much concern about chilling effects for conduct that is already prohibited under a law that passes constitutional muster, and any concerns about the constitutionality of such laws should be addressed under the complex constitutional precedent that has evolved concerning regnlations of political conduct. ${ }^{226}$ Moreover, if antitrust judges merely apply prevailing and pre-defined legal standards rather than formulate their own as they go along, the risk that some sides will be favored in political debates will be lower.

\section{Validity in the Adjudicative Process}

Antitrust immumity is narrower in the adjudicative process. California Motor refused to immunize petitioning efforts within the administrative or judicial processes that violated the standards of those processes, even though those efforts would have been valid within the political process. ${ }^{27}$ In dicta the Court suggested that any unethical or deceptive conduct which was illegal under the rules governing the process in question would not receive antitrust immunity. ${ }^{228}$

In other words, process standards vary in stringency depending on the context, and lesser standards apply in the political context than in the adjudicatory one. ${ }^{229}$ This is different from saying that lesser standards apply if the ultimate goal is legislative action instead of a court judgment. "A misrepresentation to a court would not necessarily be entitled to the same antitrust immunity allowed deceptive practices in the political arena simply because the odds were very good that the court's decision

225. Eastern R.R. Presidents Conference v. Noerr Motor Freight, 365 U.S. 127, 132-35 (1961).

226. Id. at 141 (arguing that antitrust review of political activities would upset the Court's cautious precedent concerning legislation that regulates political activities).

227. See California Motor Transp. Co. v. Trucking Unlimited, 404 U.S. 508, 512-13 (1972).

228. Id.

229. See Allied Tube \& Conduit Co. v. Indian Head, Inc., 486 U.S. 492, 499-500 (1988); California Motor, 404 U.S. at 512. 
would be codified ...."230 The key is the process context, not the type of governmental result.

The actual conduct before the California Motor Court was the defendants' policy of instituting hitigation, "with or without probable cause," to oppose licenses for their competitors. ${ }^{231}$ This, the Court held, was an "abuse of process" invalid within the standards historically applicable to courts or agencies acting in an adjudicatory capacity. ${ }^{232}$ Accordingly, no antitrust immuinty apphed. ${ }^{233}$ But the abuse of process rationale for denying immunity has proven confusing to the lower courts. $^{234}$

In part the confusion lias resulted because, following California Motor, courts and commentators continue to unisname this the "sham" litigation exception. ${ }^{235}$ This nomenclature lias often produced stramed efforts to treat strategic hitigation as true shams; in other words, litigation not genuinely intended to win the adjudication. But as demonstrated above, the conduct in California Motor was genuinely intended to influence adjudication and was successful at it more than fifty percent of the time. ${ }^{236}$ The fault with the conduct, rather, lay in the pohicy of automati-

230. Allied Tube, 486 U.S. at 504.

231. California Motor, 404 U.S. at 512.

232. See id. at 513.

233. Id.; see also Otter Tail Power Co. v. United States, 410 U.S. 366, 367, 380 (1973) (finding no immunity for repetitive insubstantial claims).

234. See Calkins, supra note 9, at 327-28 (noting courts' confusion); Minda, supra note 24 , at 965 (same).

235. See, e.g., AREEDA \& HovenKAMP, supra note 10, fi 203.1, at 18-34.

236. See supra text accompanying notes $46-47,85-91$. Nor is it fair to say that the Supreme Court in California Motor sustained the complaint only as to those of the 40 legal proceedings that lacked probable cause. For, as the district court made clear, the complaint carefully refrained from charging that any of the 40 proceedings was in fact instituted without probable cause. See Trucking Unlimited v. California Motor Transp. Co., 1967 Trade Cas. (CCH) 1 72,928, at 84,744 (N.D. Cal.), rev'd on other grounds, 432 F.2d 755 (9th Cir. 1970), aff'd on other grounds, 404 U.S. 508 (1972). Rather, the gravamen of the complaint was that the defendants were instituting proceedings automatically, without really considering the merits or whether or not probable cause existed. See id. (Allegations that any specific proceeding lacked probable cause would have been difficult to sustain since all the proceedings concerned applications for trucking licenses, which could be denied under a relatively discretionary "public convenience and necessity standard," and the defendant had obvious success in obtaining frequent denials under that standard in similar cases.) Nothing in the Supreme Court's opinion suggested it disagreed with the district court's interpretation of the complaint, nor that the complaint should be amended to include only proceedings instituted without probable cause. To the contrary, the fact that the Court in California Motor felt obliged to discuss whether other invalid means of actually influencing adjudication should get antitrust immunity, see 404 U.S. 508, 512-13 (1972), suggests it recognized that the case could not be disposed of merely by stating the defendants' conduct was not genuinely intended to influence the government. Indeed, the Court explicitly stated that it was not using "sham" in the same sense as in Noerr, but that it had "adapted" the exception to fit the adjudicatory process. See id. at 516; see also id. at 512-13 (making clear that activities deemed a sham in the adjudicative process would differ from those deemed a sham in the political process). (Similarly, the court of appeals did not rejeet the district court's interpretation of the complaint, but instead concluded that the sham exception applied because the defendant's "primary" purpose was to directly harm competitors. See 432 F.2d 755, 762-63 (9th Cir. 1970) aff'd, 404 U.S. 508 (1972)). 
cally litigating no matter what the chance of winning. ${ }^{237}$ Thus even a suit with probable cause can be subject to antitrust liability under California Motor, ${ }^{238}$ not because the suit is a true sham, but because of the special abuse of process standards applicable in litigation. ${ }^{239}$

This analysis helps resolve one issue that has confused courts: the applicability of the abuse of process rationale to the political process. Lobbying in the face of almost-certain defeat, no inatter how often repeated, is not an abuse of process under governing political norms. Indeed, such determined pohtical lobbying might be regarded as admirably fighting for one's cause. Few think that the Libertarian Party should be prohibited froin fielding a presidential candidate because its candidates have repeatedly lost before. Nor is there anything to prohibit advocates from pressing for an Equal Rights Amendinent even if it seems clear that they will lose again; after all, women's suffrage was finally extended after decades of repeated losses. In contrast, a policy of litigating regardless of the chance of winning is condeinned because it imposes enormous costs on the particular individuals being sued. ${ }^{240}$

A second issue raised by the abuse of process rationale for denying immunity to strategic hitigation is why the anticompetitive injury in such cases should be regarded as flowing froni private action. Doesn't the injury actually result fronı governinental coercive power; nainely, the power of courts and agencies to force parties to participate in adjudicatory proceedings? Why, then, is the injury not considered the result of governmental action? ?41 $^{41}$

The answer is that the mjury results no niatter what the government official decides. The government has essentially delegated to litigants the

237. See Califormia Motor, 432 F.2d at 762-63 ("Since all applications were to be opposed, it is irrelevant that a valid basis existed for opposing some applications.").

238. See In re Burlington N., Inc., 822 F.2d 518, 527-28 (5th Cir. 1987) (denying immunity even though petitioning had been partially successful), cert. denied, 484 U.S. 1007 (1988); Calkins, supra note 9, at $362 \mathrm{nn} .178-79$ (collecting sources holding or arguing that suceess should not be dispositivc); sources cited infra note 239 . The Ninth Circuit reached a contrary decision in Columbia Pictures Industries v. Professional Real Estate Investors, 944 F.2d 1525 (9th Cir. 1991), cert. granted, 112 S. Ct. 1557 (Mar. 30, 1992), which is currently before the Supreme Court, and which I discuss infra at text accompanying notes 256-76.

239. See Grip-Pak, Inc. v. Illinois Tool Works, 694 F.2d 466, 472 (7th Cir. 1982) ("The existence of a tort of abuse of process shows that it has long been thought that litigation could be used for improper purposes even when there is probable cause for the litigation."), cert. denied, 461 U.S. 958 (1983); Note, Limiting the Antitrust Immunity for Concerted Attempts to Infiuence Courts and Adjudicatory Agencies: Analogies to Malicious Prosecution and Abuse of Process, 86 HARV. L. REV. 715 (1973). The distinction between "sham" petitioning and "abuses of administrative or judicial processes" was recognized in Allied Tube, which treated them as separate reasons for denying immunity. Allied Tube \& Conduit Corp. v. Indian Hcad, Inc., 486 U.S. 492, 500 \& n.4 (1988).

240. See generally California Motor, 404 U.S. at 511.

241. Cf. Edmonson v. Leesville Concrete Co., 111 S. Ct. 2077, 2082-87 (1991) (finding constitutional state action when private lawyers in civil cases use litigation procedures to exclude black jurors). 
power to submit others to the costs and delays of litigation. True, these costs and delays reflect the exercise of an autliority enforced by the government, but that is also trne when antitrust defendants exercise their coinınon law property riglits in order to fix prices or restrict sales. ${ }^{242}$ Because no disinterested accountable decisionmaker has made a substantive decision in favor of the terms of restraint, no immunity should or does apply. ${ }^{243}$

Of course, this ineans that the petitioner should enjoy immunity for any injury inflicted by substantive court decisions in such cases. The antitrnst plamtiff seeking recovery for the defendant's strategic litigation can recover daniages only for the costs and delays imposed by having to defend against that higation. ${ }^{244}$

A third issue is wlyy and when the costs and delays inposed by litigation, however mjurious, should be considered anticompetitive. Sometimes, of course, this is relatively clear. The defendants' decision to litigate may delay a competitor from getting the regulatory approval necessary to enter the market. Entering a market nowadays can require approvals from a myriad of licensimg boards, zoning commissions, and environmental regulators. A firm that is repeatedly opposed in such proceedings witlout regard to the legal merits can have its entry to the inarket delayed for a long time.

But anticonıpetitive mjury can also result even when litigation delay does not directly bar market entry. Firms might litigate strategically to increase their competitors' costs. ${ }^{245}$ An objection raised against this theory of strategic litigation is that litigation miposes expenses on both sides. ${ }^{246}$ But there are two persuasive responses to this objection.

First, a threat to inflict proportionate costs on both sides can still deter competition if the threatener can make a credible commitment to inflict those costs regardless of the injury lie himself suffers. ${ }^{247}$ The nuclear deterrence of mutual assured destruction is one instance of such a strategy. For a less rarified exainple of the importance of commitinent,

242. See Elhauge, supra note 25 , at $680-81$.

243. Where the government has made such a substantive decision by controlling the duration of the delay, the Court has been willing to provide both petitioning and state action immunity from antitrust liability. See New Motor Vehicle Bd. v. Orrin W. Fox Co., 439 U.S. 96, 109-11 (1978).

244. See, e.g., Rickards v. Canine Eye Registration Found., 783 F.2d 1329, 1334-35 (9th Cir.) (declaring that the cost of defending against sham litigation constitutes antitrust injury), cert. denied, 479 U.S. 851 (1986).

245. See Hurwitz, supra note 10, at 70-73; Christopher C. Klein, Strategic Sham Litigation: Economic Incentives in the Context of the Case Law, 6 INT'L REV. L. \& EcoN. 241 (1986). These costs include not only legal fees but also the time costs of participating in litigation, which distracts management from business operations, and possible capital costs if the litigation makes it harder or more expensive for the defendant to raise capital.

246. See Minda, supra note 24, at 964 n.206.

247. See Klein, supra note 245 , at 244 . See generally Thomas C. Schelling, The Strategy of CoNFLICT 22-28 (1960) (explaining how a prior commitment can improve one's bargaining power). 
consider the game of "chicken." In this game two persons drive their cars toward each other with the result that either a head-on collision occurs or one driver pulls off the road and becomes the "chicken." The driver who can make a binding commitınent to stay on the road despite the risk of head-on collision should win because the costs to the other driver of a head-on collision far outweigh the costs of being called "chicken." One such commitınent might consist of taking one's hands off the wheel. A better commitinent would be reinoving the steering wheel and throwing it out the window.

In California Motor, the commitment consisted of forming a joint trust fund to oppose all applications by coinpetitors for operating rights. $^{248}$ This committed the defendants to spending inoney on litigation by turning the legal authority to do so over to the trustee. Of course, such commitinents can ouly have their desired effect if they are cominunicated to the parties sought to be deterred. Thus, in California Motor, the defendants explicitly warned their competitors about tlieir plan and informed them that they could avoid the costs of hitigation only by refraining froin entering the market. ${ }^{249}$

Second, litigation can often disproportionately raise the coinpetitor's costs. Sonetines hitigation expenses are asymmetric: opposing the litigation may cost inore than initiating it. ${ }^{250}$ Further, miposing the same expenses on both sides can have asymmetric effects. If, for example, the litigation is between a large and small producer, then imposing the saine litigation expenses on both sides will increase the sinall producer's cost per output more than the large producer's. ${ }^{251}$

Such strategic hitigation is actually a far more useful tool for driving coinpetitors out of business than predatory pricing. ${ }^{252}$ Predatory pricing costs a large producer more than a sinall producer, because the large producer must lower prices on inore sales. Predatory litigation does not have this limitation, and can tlius inflict greater per unit costs on small producers than the large producer suffers. ${ }^{253}$

248. See Trucking Unlimited v. California Motor Transp. Co., 1967 Trade Cas. (CCH) I 72,298 , at 84,740 (N.D. Cal.), rev'd on other grounds, 432 F.2d 755 (9th Cir. 1970), aff'd on other grounds, 404 U.S. 508 (1972).

249. Trucking Unlimited v. Califormia Motor Transp. Co., 432 F.2d 755, 762 (9th Cir. 1970), aff'd, 404 U.S. 508 (1972).

250. Hurwitz, supra note 10 , at 71 .

251. See AREeDA \& HOVENKAMP, supra note 10, | 203.1a, at 21 n.20; Hurwitz, supra note 10, at 71; Klein, supra note 245, at 248.

252. See 24 Trade Reg. ReP. (CCH Extra Edition, Nov. 10, 1988) (Department of Justice Guidelines, International Operations Antitrnst Enforcement Policy); ROBERT H. BORK, THE ANTITRUST PaRadox 357 (1978).

253. Using litigation to raise rivals' costs does not affect the marginal cost of their production, and thus should not directly affect market prices. See Klein, supra note 245, at 244. It can, however, affect market prices indirectly if the competitor sues for peace, for example by not charging certain prices or by not competing for certain customers. It can also affect market prices if the competitor is driven out of the market or deprived of the funds it needs to expand. 
Of course, using litigation to impose costs on competitors cannot, in general, have any anticompetitive effect unless the defendants exercise or orchestrate the market power to raise prices once their rivals' costs (or behavior or existence) have been changed. ${ }^{254}$ Because the warrant for imposing antitrust liability-rather than ordinary tort liability for abuse of process-is that strategic litigation abuse miglit affect competition, this suggests that market power should be a necessary element to finding antitrust liability for abuse of process litigation. Moreover, market power is a prerequisite to liability under the Sherman Act except for certain per se violations, ${ }^{255}$ and it would be inappropriate to treat abuse of process litigation as a per se violation because such litigation is often difficult to distinguish from meritorious litigation.

This brings us to the fourth issue, which is the one that has most perplexed courts and commentators, and which is currently pending before the Supreme Court: how can a court determine when a litigant has engaged im abuse of process hitigation? ${ }^{256}$ A typical statement is that "[t]he line is crossed when [the defendant's] purpose is not to win a favorable judgment against a competitor but to harass him, and deter others, by the process itself-regardless of outcome-of litigatimg."257 But it is hard to find the hitigant who does not have both aims. The most strategic of litigants genuinely lope they win, even if the odds may not look good, and the most nonstrategic of litigants usually dislike their opponents enough to take soine pleasure in inflicting litigation costs on them.

If a genuine hope of winning sufficed to receive immunity, then abuses of process would effectively go undeterred, and predatory litigation would flourish. If, on the other hand, a purpose of harassing opponents sufficed to lose immunity, then firms would fear to brimg even meritorious litigation against their competitors. The mere existence of either motive should thus not suffice to establish immumity or non-inmumity. Some weighing of the motives must be made.

One method is to determine the defendant's subjective intent, ${ }^{258}$ which where motives are mixed means determining which motive subjectively doninated the defendant's mind. This approach is in some tension with the general objective process approach, but is perhaps justified

254. See Edward A. Snyder \& Thomas E. Kauper, Misuse of the Antitrust Laws: The Competitor Plaintiff, 90 MICH. L. REV, 551, 564 (1991).

255. AREEDA \& HOVENKAMP, supra note $10, \uparrow 203.6$, at 61 .

256. See Columbia Pictures Indus. v. Professional Real Estate Investors, 944 F.2d 1525 (9th Cir. 1991), cert. granted, 112 S. Ct. 1557 (Mar. 30, 1992).

257. Grip-Pak, Inc., v. Illinois Tool Works, 694 F.2d 466, 472 (7th Cir. 1982), cert. denied, 461 U.S. 958 (1983); see also City of Columbia v. Omni Outdoor Advertising, 111 S. Ct. 1344, 1354 (1991) (making a similar statement).

258. See Kintner \& Bauer, supra note 11, at 571-72 nn.97-98 (collectimg sources focusing on intent). See generally Gilson, supra note 162 , at $880-82$ (discussing inherent difficulties in determining the subjective intent of plaintiffs). 
because the prevailing regulatory standards-abuse of process normsincorporate a primary intent test. ${ }^{259}$ Nonetheless, an objective test for determining intent is preferable for the reasons articulated above. ${ }^{260}$ Subjective intents are too easy to hide-and allege. Courts required to determine subjective intents will thus be forced to speculate about something that is, in truth, largely unknowable. Worse, because the inquiry is so unstructured, deteruminations of subjective motive will likely be influenced by the hidden biases of judges and juries against (or for) certain types of litigation or litigants.

Three principal efforts have been made to give objective content to the process/outcome intent test. One asks whether the chances of winning were "reasonable," 261 which can be much the same as asking whether there was "probable cause" to bring the suit. ${ }^{262}$ This test entails examinimg the extent of legal and factual support for the party's position. ${ }^{263}$ But penalizing hitigation whenever the chances of success are low would bar "creative" legal arguments from legal discourse. ${ }^{264}$ And it is hard to see what plausible test based on the chances of winning could possibly explain excluding a litigant with a $52.5 \%$ success rate, as California Motor did. ${ }^{265}$ If, in response to these problems, one interprets the reasonable expectation test as referring to something other than the likehhood of success, tlien the test offers no guidance at all because which expectations are "reasonable" becomes a completely conclusory judgment. $^{266}$

A second test asks whether the motive of securing judicial relief was a "significant" factor behind the decision to sue. ${ }^{267}$ Unfortunately, this test also leaves the judicial inquiry unstructured. Not only is there no definition of what "significant" ineans, but the criteria that would go into deciding significance are left uncertain. The test does suggest that courts

259. See Restatement (SECOND) OF TORTS $§ 682$ (1976).

260. See supra text accompanying notes $162-63$.

261. See Litton Sys. v. American Tel. \& Tel., 700 F.2d 785, 810 (2d Cir. 1983), cert. denied, 464 U.S. 1073 (1984); see also AREEDA \& HoveNKAMP, supra note 10, $\Uparrow$ 203.1, at 23.

262. See, e.g., Columbia Pictures Indus. v. Professional Real Estate Investors, 944 F.2d 1525, 1532 (9th Cir. 1991) (equating probable cause and reasonable basis), cert. granted, $112 \mathrm{~S}$. Ct. 1557 (Mar. 30, 1992).

263. See Gilson, supra note 162 , at $879-80$.

264. See AREeDA \& Hovenkamp, supra note 10, $\Uparrow 203.1 \mathrm{e}$, at 31; Gilson, supra note 162, at 879-80; Hurwitz, supra note 10, at 98.

265. See supra text accompanying notes $46-47,85-91$; see also note 236 and accompanying text. The Ninth Circuit's opinion in Columbia Pictures contains no mention of the success rate of the litigants in California Motor, suggesting the appellate panel was perhaps unaware of it.

266. Professors Areeda and Hovenkamp, for example, reject a test based on the probability of winning, reasoning: "[O]ne must not penalize the assertion of novel legal claims. Such claims sometimes prevail. That a claim is novel or against the weight of precedent does not make it unreasonable." AREEDA \& HovenKAMP, supra note 10, $\mid$ 203.1e, at 31. Unfortunately, Areeda and Hovenkamp do not tell us what does suffice to make a claim unreasonable.

267. See Coastal States Mktg. v. Hunt, 694 F.2d 1358, 1372 (5th Cir. 1983). 
should look not only at the chances of success but also at the stakes for the litigating party, since both no doubt affect decisions to litigate. ${ }^{268}$ But the test fails to explain how courts should weigh these factors.

Judge Posner has offered a more structured approach. In Grip-Pak, he stated that there should be no immuinty when the value of a favorable judgment, discounted by the uncertainty of prevailing, is less than the cost of suit. ${ }^{269}$ The main objection to this test is that it discourages the filing of legitimate or novel claims, ${ }^{270}$ especially when one takes into account the possibility of judicial error. But this objection is not dispositive because any doctrine can offer at best imperfect regulation. Efforts to deter undesirable conduct inevitably deter some desirable conduct, and the best we can hope for is a system that achieves the optimal tradeoff. ${ }^{271}$ Here the unavoidable tradeoff is between deterring predatory hitigation and deterring legitimate suits; we calmot deter the former without deterring soine of the latter. ${ }^{272}$

Nonetheless, a number of factors suggest that Posner's test overly constricts immunity. His test effectively demies immunity whenever the prospect of victory is not a sufficient motive for litigation, or, to put the matter another way, whenever the direct injury to competitors is necessary to motivate litigation. But if both this direct injury and the prospect of favorable judgment are necessary motives for litigation (and thus neither is a sufficient motive), one cannot say that one inotive is greater than the other.

Posner's objective test accordingly seems somewhat biased toward finding an abusive intent. If anything, the opposite bias seems advisable. Legitimate suits are already somewhat deterred by their costs, and those same costs offer some self-deterrence to strategic litigation. This suggests a greater need to encourage legitimate suits than to deter strategic suits.

268. See Sullivan, supra note 10 , at 363 .

269. See Grip-Pak, Inc. v. Illinois Tool Works, 694 F.2d 466, 472 (7th Cir. 1982), cert. denied, 461 U.S. 958 (1983); see also Premier Elec. Constr. Co. v. National Elec. Contractors Ass'n, 814 F.2d 358, 372 (7th Cir. 1987) (Easterbrook, J.) (reaffirming Posner's position).

270. See Klein, supra note 245 , at 245.

271. See Einer Elhauge \& Stephen Bundy, Knowledge About Legal Sanctions 3-11 (John M. Olin Working Paper in Law \& Economics, No. 91-9) (on file with the California Law Review) (Part I); Einer Elhauge, The Triggering Function of Sale of Control Doctrine, 59 U. CHI. L. REv. (forthcoming Fall 1992) (manuscript at 33-37, on file with author) (Section III.A).

272. See Klein, supra note 245, at 245-51; see also Paul L. Joskow \& Alvin K. Klevorick, $A$ Framework for Analyzing Predatory Pricing Policy, 89 Y ALE L.J. 213 (1979) (arguing that antitrust bans on predatory pricing must balance the benefit of deterring predatory pricing against the cost of deterring desirable price-cutting). The same tradeoff is present for non-antitrust doctrines that deal with the problem of frivolous suits and strategic litigation. See Gilson, supra note 162, at 877-82 (arguing with respect to malicious prosecution and professional rules of conduct that any definition of strategic litigation must trade off over- and underinclusion); Avery Katz, The Effect of Frivolous Lawsuits on the Settlement of Litigation, 10 INT'L REv. L. \& EcoN. 3, 26 (1990) (concluding that the English rule of assessing legal expenses against the loser may help deter frivolous suits, but only at the cost of deterring meritorious suits). The discussion in the text thus also applies to those doctrines. 
Further, an antitrust suit brought to challenge strategic litigation carries with it the threat of treble damages. These treble damages, coupled with the direct costs inflicted on an opponent by a suit alleging strategic litigation, mean that the threat of a "sham-sham" suit (i.e., a suit falsely alleging the other side engaged in strategic hitigation) will likely carry greater weight than the threat of a "sham" (i.e., strategic) suit. ${ }^{273}$

A better test would deny antitrust immumity only if the direct injury was a necessary and sufficient objective motivation for the allegedly strategic hitigation. Under this two-part test, the antitrust plaintiff alleging strategic litigation would (im addition to defendant market power) have to show: (1) that the antitrust defendant would not have brought the original suit but for the direct injury imposed on his competitor, and (2) that the defendant would have brought suit even without any prospect of winning in order to inflict the direct costs or delays on his competitor. This test fits better with the significant motive test, ${ }^{274}$ and provides some objective content to the reasonable expectation test. It also lessens the risk that antitrust suits will deter novel and legitimate litigation because it demies immunity only if the direct injury alone would cause the antitrust defendant to sue (and the expected value of winning would not), which is certainly not true for most novel or imaginative claims. The risk is further lessened under my test because litigants would suffer no antitrust liability uuless they have been proven to have a market power to raise prices that will be maintained, created, or strengthened by the infliction of litigation costs or delays on their competitors. ${ }^{275}$ While there will no doubt be uncertaimties in the test's application, it structures the judicial inquiry far more than the conclusory reasonable expectation or significant motive tests ever could. ${ }^{276}$

273. See Klein, supra note 245 , at 249 . Treble damages pose a threat because of the inevitable possibility of false positives: that is, unwarranted findings that the original suit was strategic or predatory.

274. The courts using the significant motive test have relied not just on evidence that the suit was not reasonably founded but also on evidence that the defendant would have sued to impose direct costs even without any prospect of winning. See In re Burlington N., Inc., 822 F.2d 518, 528 (5th Cir. 1987), cert. denied, 484 U.S. 1007 (1988).

275. See supra text accompanying note 254-55.

276. Proving strategic litigation will be easier if the defendant has engaged in repetitive litigation, but one-shot lawsuits can also constitute strategic litigation outside the scope of petitioning immunity. See AREEDA \& HovenKAMP, supra note 10, ๆ 203.1e, at 31-32 (collecting cases); Handler \& De Sevo, supra note 35, at 28-30 (same); Hurwitz, supra note 10, at 101 \& n.160 (same); Kintner \& Bauer, supra note 11, at 574 n.110 (same). Nor, despite some language in California Motor Transportation Co. v. Trucking Unlimited, 404 U.S. 508, 515 (1972), does it seem necessary to show that the defendant's actions barred the antitrust plaintiff from access to the adjudicatory process. See AREedA \& HovenKamp, supra note 10, ๆ 203.1b, at 22-23 \& n.31 (collecting cases); Hurwitz, supra note 10, at 101-02 \& n.165 (same). Both these legal conclusions comport with the analysis offered here. Competitors (and, through them, competition) can be hurt by enduring the costs of strategic litigation even though only one suit is brought and even if the costs are not so high as to totally deprive the party of access to the courts. 


\section{Validity in the Private Process}

Allied Tube presented a somewhat more perplexing case. The defendants there chose to influence the government and the market indirectly, by influencing a private standard-setting association to adopt an electrical code that excluded plastic conduit. To some extent, this injured the plaintiffs because the code constituted an implicit agreement by association members to boycott the plaintiff's product. To that extent, the defendants' conduct imvolved market behavior which, as discussed above, is outside the scope of antitrust immunity. ${ }^{277}$

Had the plaintiff's entire injury resulted solely from this collective market behavior, the Court could have stopped with that observation. But much of the plaintiff's injury was reputational. The code's conclusion that plastic conduit was unsafe had a strong influence on non-association members: if a product fell outside the code, private certification laboratories would not certify it, underwriters would not insure it, and many inspectors, contractors, and distributors would not use it. ${ }^{278}$ To determine whether the defendant was immune from danages for these reputational injuries required determining whether the defendant's conduct was valid within the ordimary standards applicable to the context. Here the context was a standard-setting association that was "private" in the sense that the Court uses the term because it comprised inarket participants and was thus financially interested. ${ }^{279}$ One might represent this decisionmaking process by Diagram $\mathrm{K}$.

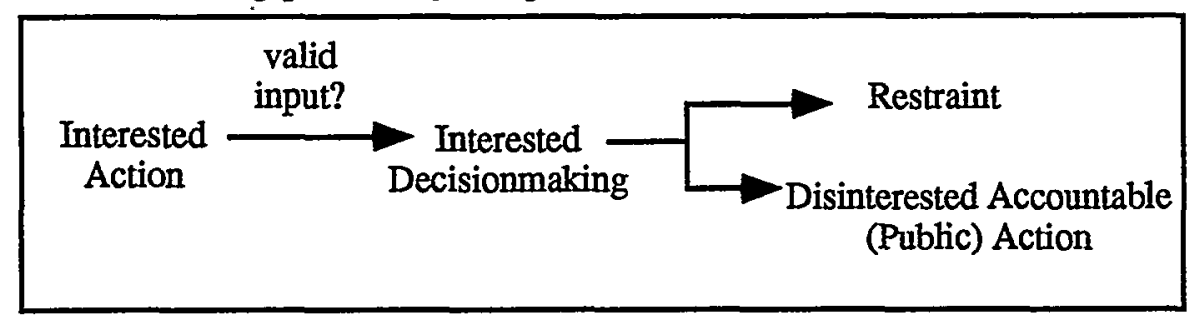

\section{Diagram $K$}

277. See supra note 205 and accompanying text.

278. See Allied Tube \& Conduit Corp. v. Indian Head, Inc., 486 U.S. 492, $495-96$ (1988).

279. In denying immunity, the Court emphasized that the defendants exercised decisionmaking authority over an association that comprised market participants with financial interests at stake. Id. at 501-02, 506-07. Although Professors Areeda and Hovenkamp suggest that immunity might still apply to "'normal' voting" by financially interested association members, AREEDA \& HovenKAMP, supra note 10, I 206.2, at $86-87$, this suggestion is unfounded. The Court explicitly rejected the notion that complying with association rules should provide immunity. Allied Tube, 486 U.S. at 509. Moreover, the Court held that where "an economically interested party exercises decisionmaking authority in formulating a product standard for a private association that comprises market participants, that party enjoys no Noerr immunity from any antitrust liability flowing from the effect the standard has of its own force in the marketplace." Id. at 509-10. Anyone voting clearly exercises "decisionmaking authority," and voting by financially interested actors-whether "normal" or not (assuming that could be defined)-creates the sort of decisionmaking process calling for antitrust review. 
The question was what provides the ordinary process standards in this context. In part such standards are provided by the rules of the standard-setting association, under which the defendants' conduct in packing the ineeting (while unsavory) was valid. ${ }^{280}$ But the perplexing facet of the case was that, irrespective of association rules, the legal standards governing the private standard-setting process are largely those provided by antitrust law itself. ${ }^{281}$ Accordingly, when the Court incorporated the process' prevailing regulatory standards to decide whether the conduct was invalid in a way that abrogated antitrust iinınunity, it had to incorporate the standards of antitrust review itself. In short, "[t]he issue of immunity in this case thus collapses into the issue of antitrust hability."282

This conclusion should not be misinterpreted as meaning, as the lower court held in Allied Tube, ${ }^{283}$ that indirect efforts to petition the government by petitioning a private organization should not receive antitrust immunity. I1nagine, for example, that DuPont petitions the Democratic Party or the Sierra Club to adopt organizational platforms calling for governmental restrictions on fluorocarbons. An antitrust suit is brought alleging that DuPont is financially interested because, unlike its coinpetitors, it has alternative means of producing spray cans that do not use fluorocarbons. Under the Court's doctrine, antitrust iminunity would still apply as long as DuPont's efforts conformed with the ordinary pohitical standards governing efforts to influence political parties and organizations. ${ }^{284}$. Under the lower court's direct/indirect distinction, immumity would not have apphed because no public official was directly petitioned. Such a direct/indirect distinction would have seriously restricted petitioning rights because the real movement of political ideas generally occurs not in legislative hearings but in the countless private fora that create organizational agendas and inold public opinion. A denial of immumity for indirect petitioning would thus have been chilling indeed to First Amendinent freedoms.

We are now in a position to unpack what has been lumped together as a "commercial" exception to antitrust petitioning immunity. Cominerciality, the discussion so far demonstrates, may be relevant in no less than three distinct senses. First, the governinental action may be coinmercial in the sense that the government or its officials have a financial interest in the governinent's restraint of trade. This would deprive the petitioner of immunity for any direct restraints and, where it shares deci-

280. See Allied Tube, 486 U.S. at 509.

281. See id. at 500-01, 506-07.

282. Id. at 509.

283. Indian Head, Inc. v. Allied Tube \& Conduit Corp., 817 F.2d 938, $945-46$ (2d Cir. 1987), aff'd on other grounds, 486 U.S. 492 (1988).

284. Accordingly, the Allied Tube Court rejected the direct/indirect distinction, noting that the petitioning in Noerr itself was indirect. Allied Tube, 486 U.S. at 503. 
sional responsibility, for the government's restraint. Second, the defendant's conduct may involve financially interested market behavior. The petitioner would still be immune for the government's restraint unless the government was coerced, but would not have immunity for any direct effects of the market behavior. Finally, the commerciality of the governmental activity or the petitioning may determine the appropriate contextual standard to judge the validity of the petitioning. Where this commercial context means the petitioning is imvalid, its direct effects enjoy no immunity, but the governmental action normally does.

\section{Political Boycotts that Do Not Coerce the Government}

We come next to the topic of non-coercive political boycotts; that is, boycotts designed to raise consciousness and influence public opimion whiclı do not cóerce tlie government. For example, suppose gas stations agree to close during certain periods to protest governmental price regulations. Should this boycott be immune? So far, courts have split on the issue. $^{285}$

The issue is distinguishable from that in Trial Lawyers because liere the boycotters are not boycotting or coercing the government directly. The restraint on the public lias coercive aspects, but the input into the government may not be coercive. The issue is thus closer to that in Allied Tube: market behavior that produces both a financially interested restraint and persuasive input into the political process. Nonetheless, there may be some indirect coercion of the government if the boycott coerces voters to in turn exert pressure on the political process.

In any event, whether under Allied Tube or Trial Lawyers, the analysis above suggests that if the boycotters liave a financial interest in the boycott, no immumity should apply. This is supported by dicta in Allied Tube, which listed a parade of horribles intended to slow the unacceptable consequences of the absolutist position that immunity applies to all activity genuinely intended to influence the government. Among the unacceptable liorribles, the Court included:

Horizontal conspiracies or boycotts designed to exact higher prices or other economic advantages from the government would be immunized on the ground that they are genuinely intended to influence the government to agree to the conspirators' terms. Firms could claim immunity for boycotts or horizontal output restrictions on the ground that they are intended to dramatize the plight of their industry and spur legislative action. $^{286}$

The two sentences signal the Court's understanding of the distinction

285. Compare Osborn v. Pennsylvania-Del. Serv. Station Dealers Ass'n, 499 F. Supp. 553, 558 (D. Del. 1980) (not immune) with Crown Cent. Petroleum Corp. v. Waldman, 486 F. Supp. 759,769 (M.D. Pa.) (immune), rev'd on other grounds, 634 F.2d 127 (3d Cir. 1980).

286. Allied Tube, 486 U.S. at 503 (citation omitted). 
between two different sorts of political boycotts, those that coerce the government and those that do not. They also indicate the Court's sentiment that (at least where financially imterested) neither merits immunity. Trial Lawyers echoed both sentiments, ${ }^{287}$ as well as providing the holding that cemented the first.

Where the boycotters have no financial imterest in the anticompetitive consequences of the boycott - that is, they do not benefit financially either from lessening coinpetition in the boycotted inarket or froin inducing the boycotted parties to lessen coinpetition in other inarkets-the issue is different. To soine extent, such financially disinterested boycotts are immunized under Claiborne Hardware, where the boycott to end racial discrimmation was aimed not only at government officials but also at private merchants. ${ }^{288}$ And, as I argue above, because such disinterested action cannot usefully be channeled into a coinpetitive process, antitrust review may be unhelpful from an objective process standpoint. $^{289}$

This distmction between financially interested and disinterested boycotts provides a sounder basis for the decision in Missouri v. National Organization for Women (NOW) than the Eighth Circuit was able to provide. ${ }^{290}$ That case concerned a boycott, organized by NOW, of convention facilities located in states that had not ratified the Equal Rights Amendment. The Eighth Circuit held that the boycott was inmune because (1) the ultimate goal was political, not econornic, legislation and (2) the boycotters were motivated by political objectives, not profit. ${ }^{291}$

Unfortunately, both these tests are anbiguous and raise the specter of sub rosa judicial bias. How can we tell that the Equal Rights Amendment is pohtical and not econoimc? Surely it would re-order economic relations in einployment. And what about other boycotts, like one designed to encourage bans on allegedly unsafe products? Such bans may have noneconomic objectives, but they restrict coinpetition. The inevitable risk is that judges will tend to conclude that the sort of legislation they favor is political and the sort they disfavor is inerely economic. Perhaps judges can discipline themselves to avoid this tendency, but without any intelligible criteria for sorting political from econoinic legislation, they have little else to rely on besides their gut intuitions. In any event, the judicial ability to resist the temptation to impose judicial views is not limitless. Like other scarce items, it should be econounized. Sinilar probleins beset a test focusing on whether the boycotters were subjec-

287. FTC v. Superior Court Trial Lawyers Ass'n, 493 U.S. 411, 425 (1990) (quoting Allied Tube, 486 U.S. at 503).

288. See supra text accompanying notes 165-67.

289. See supra text accompanying note 164 .

290. 620 F.2d 1301 (8th Cir.), cert. denied, 449 U.S. 842 (1980).

291. Id. at 1311-12. 
tively motivated by financial gain or by political objectives, and for that reason subjective motives are not used under the functional process approach-or the Court's case law-in determining whether antitrust immunity apphies. ${ }^{292}$

What should have been considered decisive was the fact that, objectively speaking, the boycotters im NOW had no financial interest in any anticompetitive consequences of the boycott. They did not compete with convention facilities and had nothing financial to gain from lessening competition im the convention market. ${ }^{293}$ To be sure, some of the boycotters might have gamed financially if the Equal Rights Amendinent had been enacted because they would have gotten better jobs or pay. ${ }^{294}$ But one could have said the saine about the boycotters in Claiborne Hardware. In both cases, however, this financial imterest was never actually established and would in any event have been attenuated and inapplicable to many of the boycotters, especially those who were male in NOW and white in Claiborne.

More importantly, the question here is whether the boycotters had a financial interest in the anticompetitive consequences of the restraint imposed by their actions, not whether they had a financial interest in whatever governmental action inight have ultimately resulted. They are immune for any results of the governinent action, absent evidence that the government was coerced by a boycott that had market power. ${ }^{295}$ But they lose their immunity for the direct results of their boycott, with or without a showing of inarket power, if they would have benefitted financially from a lessening of coinpetition in the boycotted market or from inducing the boycotted parties to lessen competition. In NOW, the boycotters had no financial stake at all in the boycott's nongovernmental consequences, and thus rightly received immunity.

In Claiborne Hardware, the boycotters had no financial interest in lessening competition among white merchants. And although some boycotters may have had a financial imterest in directly inducing white merchants to end job discrimination, the end of such discrimination does

292. See supra text accompanying notes 161-63. See generally AREEDA \& HovenKAMP, supra note 10, I 113.1, at 7 (noting difficulty of parsing mixed motives). Also raising problems of ambiguity and sub rosa judicial bias would be a doctrine that immunized boycotts with an "expressive component." Such a doctrine was appropriately rejected in FTC v. Superior Court Trial Lawyers Ass'n, 493 U.S. 411, 428-32 (1990).

293. NOW, 620 F.2d at 1303 (summarizing lower court's factual findings). If, instead, the boycotters included hotels from states that had ratified the Equal Rights Amendment, who would have benefited financially from the shift in business from non-ratifying states, those hotels would not have merited antitrust immunity, no matter how pure they claimed their subjective motives were. Cf. AReeda \& Hovenkamp, supra note 10, If 113.1, at 6 (arguing that immunity should presumptively, but not conclusively, be denied to such hotels).

294. See AREeda \& HovenKAMP, supra note 10, II 113.1, at 6; Minda, supra note 24, at 984 n.288.

295. See supra text accompanying note 179. 
not lessen competition but increases it by making jobs available to more applicants. If instead the boycott aimed to induce white merchants to hire a minimum quota of blacks, then any financial interest for boycotters who were black job seekers would flow from direct anticompetitive consequences of the boycott (because competition for certain slots would be decreased) and no immunity would have applied. ${ }^{296}$

\section{$\mathrm{V}$ \\ LIABILITY FOR GOVERNMENTAL ACTION?}

The final issue is whether there are any circumstances where petitioners should be liable for.restraints imposed by governnental decision. I have already adverted to one such issue: petitioners should be liable for governmental restraints that resulted from petitioner coercion. ${ }^{297}$ But where the petitioner urges, rather than coerces, governmental action, then one must contend with the following language from Allied Tube (quoting Noerr): " '[W]here a restraint upon trade or nonopolization is the result of vahid governmental action, as opposed to private action,' those urging the governmental action enjoy absolute immunity from antitrust hability for the anticompetitive restraint."298 This raises the question of what, within the functional process frainework, constitutes "valid," imstead of invalid, governnental action.

\section{A. Petitioning for Invalid Governmental Action}

One possible meaning of invalid governmental action, which might seem to correspond to the meaning of invalid petitioning described above, would focus on whether the governmental action was legal within the procedural, administrative, or constitutional standards that apply to that government action. And indeed, im the past, some coininentators have argued that there should be no immumity when the petitioner seeks government action outside the scope of the government's authority. ${ }^{299}$ Immunity would, for example, be denied under this position if the petitioner obtains legislative action that violates the state constitution or agency action that exceeds the agency's statutory authority.

This position should, however, be rejected. From a functional process perspective, all that matters is whether the restraint was politically accountable and financially neutral. If it is, it should be immune from

296. See Hughes v. Superior Court, 339 U.S. 460 (1950) (upholding injunction of boycott that demanded $50 \%$ hiring of blacks); see also NAACP v. Claiborne Hardware, 458 U.S. 886, 915 n.49 (1982) (distinguishing Hughes).

297. See supra text accompanying notes $158,179$.

298. Allied Tube \& Conduit Corp. v. Indian Head, Inc., 486 U.S. 492, 499 (1988) (quoting Eastern R.R. Presidents Conference v. Noerr Motor Freight, 365 U.S. 121, 136 (1961)) (alteration in original).

299. See, e.g., L. Barry Costilo, Antitrust's Newest Quagmire: The Noerr-Pennington Defense, 66 Mich. L. REV. 333, 340-43 (1967). 
antitrust review because the rationale for antitrust scrutiny does not apply. The other legal reinedies for exceeding the government's authority should be adequate. If the so-called governmental restraint is instead financially interested, then it should be demed antitrust iminunity even if the action is otherwise legally authorized by the Constitution or by state or local law. ${ }^{300}$

Professors Areeda and Hovenkamp, and several courts, have reached a similar conclusion, arguing that immumity should apply to unauthorized governinental action, even if the defendant "knew" the action was unconstitutional or unauthorized. ${ }^{301}$ But their reasons are pragmatic. They argue that the motivational inquiry will be difficult, will rarely turn up such knowledge where governmental action was obtained, and will deter petitioning. ${ }^{302}$ The rationale here, in contrast, is conceptual. Without evidence that a financially interested process produced the restraint, the rationale for reviewing it under antitrust standards simply does not apply. This is not to deny that there are important practical arguınents for antitrust courts' refusal to deny petitioning immunity even to bad faith petitions for unauthorized governinent action, just as there are for antitrust courts' refusal to deny state action immunity even when the governnient has exceeded its authority in bad faith. ${ }^{303}$ But these sorts of ad hoc pragmatic arguinents do not form the basis of a consistent doctrine. A far clearer explanation is that financial interest, not governinental authority, is the real test.

More pertinent to the "validity" of the governinental action is whether it would receive innumity under antitrust's state action doctrine. $^{304}$ As I have argued in another article, state action ininunity does and should apply whenever the governinental actor is politically accountable and financially disinterested, but does not and should not apply when the governinental actor is financially interested. ${ }^{305}$ It follows that if the state action doctrine inmunizes the restraint causing the injury, then the functional process standards described above have been inet, and the efforts to procure that restraint should be immune from any antitrust

300. If the governmental action is authorized by federal statute, then we obviously have a question of whether the statute implicitly repeals the application of federal antitrust law. The tradition is to construe such implicit repeals narrowly. See Union Labor Life Ins. Co. v. Pireno, 458 U.S. 119, 126 (1982).

301. AREEDA \& HoveNKAMP, supra note 10, I 203.2, at 34-37; see also id. If 203.2, at 36-37 nn.5 \& 7 (collecting supporting cases).

302. See id. I 203.2, at 35-37; see also 1 AREEDA \& TURNER, supra note 105, I 202b, at 39.

303. See Elhauge, supra note 25 , at 692 (noting courts hold that the "clear authorization" requirement for state action immunity is met even when the state actors have exceeded or abused their authority in bad faith). This position has been confirmed in City of Columbia v. Omni Outdoor Advertising, 111 S. Ct. 1344, 1349-50 (1991).

304. For cases holding or suggesting that petitioning immunity should hinge on the existence of state action immunity, see AREEDA \& HovenKAMP, supra note 10, 10 203.2a, at 35 n.1. For cases holding or suggesting the opposite, see Meyer, supra note 198, at $843 \mathrm{n} .54$.

305. See Elhauge, supra note 25 , at 682-729. 
liability flowing from it. This is the best way of interpreting what the Court means when it states the governmental action must be "valid."

But this does not mean, as is sometimes simplistically said, that petitioning immunity is just the flip side of state action immunity. ${ }^{306}$ For sometimes, as we have seen above, petitioning immunity is denied (to restraints directly produced by the petitioning) even though the petitioning also produced governmental action that does and should receive state action immunity. ${ }^{307}$ Other times, the petitioner may simply be urging a financially interested government to impose a restraint. For example, suppose resident producers of a product mainly sold to out-of-towners encourage their city to set a minimum price at which the product can be sold. In that case there should be no state action immunity because the government is financially interested, ${ }^{308}$ but the petitioners should still be immune because the governmental decision is the one that sets the terms of the restraint. ${ }^{309}$ Where, on the other hand, the petitioner determines the terms of the restraimt jointly with a financially interested government (say, for exainple, by fixing the saine sale price for goods sold by both the petitioner and the government) then petitioning immunity does not apply. ${ }^{310}$

Some commentators have argued that the key question in evaluating petitioning immumity is whether governmental action is the "supervening" or "proximate" cause of the anticompetitive injury. ${ }^{311}$ Although such doctrinal formulations can provide a handy means of reaching the correct conclusions, I do not rely on causation because it is a formal conclusion driven by functional considerations. ${ }^{312}$ One could often reach opposing conclusions about who "caused" the restraint and whether the cause was "supervening." The real key is what functional considerations underlie the causal inquiry.

Suppose, for example, the question is whether immunity should

306. See, e.g., Omni, 111 S. Ct. at 1355; Donald I. Baker; Exchange of Information for Presentation to Government Agencies: The Interplay of the Container and Noerr Doctrines, 44 ANTITRUST L.J. 354, 356 (1975).

307. See supra Part IV.

308. See Elhauge, supra note 25 , at 729-38. For reasons peculiar to financially interested municipal restraints, state action immunity still applies if the restraint was authorized by the state. See id. at 736-38. But even with such state authority, dormant Commerce Clause review should strike down the price fioor if it mainly affects persons residing out-of-state. See id. at 732-35; Saul Levmore, Interstate Exploitation and Judicial Intervention, 69 VA. L. REV. 563, 575-626 (1983).

309. Accord AREedA \& HovenKamp, supra note 10, \ 212.8, at 198.

310. See supra text accompanying notes 124-39 (discussing Continental Ore); accord Sullivan, supra note 10, at 365-66. Under my analysis, though perhaps not Professor Sullivan's, immunity would be denied only if the price-fixing exploited market power against nonresidents of the government since the government would have no financial interest in exploiting its own residents.

311. See AREeda \& HovenKAMP, supra note 10, ๆ 201, at 14-15; Hurwitz, supra note 10, at 123.

312. See Guido Calabresi, Concerning Cause and the Law of Torts: An Essay for Harry Kalven, Jr., 43 U. ChI. L. REv. 69 (1975). 
apply to a monopolistic practice for which the monopolist sought and received substantive approval from a dismterested state regulator. Having received approval, the monopolist directly imposes the practice itself, so it seems debatable whether the state regulator was the "cause" of the practice, supervening or otherwise, particularly if it is not clear whetler the regulator's approval was required before the practice could be implemented. ${ }^{313}$ However, the real question in such cases is whetlier the decisioninaking process producing the restraint is sufficiently reliable to merit antitrust immunity, or whether instead its rehability depends on being subjected, via antitrust review, to the competitive process. Here, the monopolistic practice should be immunized because a disinterested accountable actor has made a substantive decision $\mathrm{m}$ its favor before the practice was imposed on the market. "Causation" is besides the point.

Likewise, causation explams neitler the existence of immumity in some cases where a restraint flows directly from the petitioning nor the factors that determine whether such immunity for direct restraints applies. For that, we must look to the functional process framework articulated above in Part IV.

\section{B. Bribery}

Suppose an unscrupulous liquor store bribes a state commissioner to deny a hiquor hicense to a potential competitor. The bribe lias produced a governmental restraint on competition. Are the briber and commissioner immune from antitrust liability for this restraint because, however invalid the bribe, the denial of the liquor license resulted from valid governmental action?

Under the objective process approach of this Article, the clear answer is "No." The decisionmaking process producing the restraimt was financially interested, and tlius not likely to advance the public interest uuless subjected (via antitrust review) to the competitive process. The decision by the bribed official sliould not get state action immunity, and the effort to bribe the official should not receive petitioning ininuunity. This conclusion conforms to lower court decisions. ${ }^{314}$

313. See generally AREEDA \& HovenKAMP, supra note 10, f 206.1, at 80-81 (discussing causation issue).

314. See Instructional Sys. Dev. Corp. v. Aetna Casualty \& Surety Co., 817 F.2d 639, 650 (10th Cir. 1987); Associated Radio Serv. Co. v. Page Airways, 624 F.2d 1342, 1358 (5th Cir. 1980), cert. denied, 450 U.S. 1030 (1981); Rangen, Inc. v. Sterling Nelson \& Sons, 351 F.2d 851, 856-57 (9th Cir. 1965), cert. denied, 383 U.S. 936 (1966); Cipollone v. Liggett Group, Inc., 668 F. Supp. 408, 410 (D.N.J. 1987). But see Cow Palace, Ltd. v. Associated Milk Producers, Inc., 390 F. Supp. 696, 702 (D. Colo. 1975). Campaign contributions, on the other hand, do not make a government official sufficiently self-interested to lose antitrust immunity. See Boone v. Redevelopment Agency, 841 F.2d 886, 895 (9th Cir.) (Sherman Act inapplicable to campaign contributions), cert. denied, 488 U.S. 965 (1988); Metro Cable Co. v. CATV of Rockford, 516 F.2d 220, 231 (7th Cir. 1975) (same); Elhauge, supra note 25, at 704 n.176 (same). There are two reasons for this conclusion. First, such contributions do not so much redound to the personal financial interest of the official as help that 
The issue has not yet been resolved by the Supreme Court because it has never adjudicated an antitrust state action or petitioning immunity case involving the bribery of a public official. ${ }^{315}$ The Court has, however, issued conflicting dicta on the topic. In California Motor and Allied Tube, the Court recognized that a bribery exception to petitioning immumity existed. ${ }^{316}$ The Omni opmion, on the other hand, contained dicta to the contrary. In the course of (correctly) rejecting the general proposition that immumty should be denied to governmental action when a petitioner has violated some other state or federal law, ${ }^{317}$ the Court rejected the specific proposition that immumity should be denied when a government official is bribed. ${ }^{318}$ The statements were dicta because there was

official stay in office. Since most legislators could earn far more outside office, presumably their desire to stay in office reflects their desire to exercise their political judgment on other issues, not a desire for financial gain. Second, campaign contributions are a thoroughly legal (indeed constitutionally protected, see Buckley v. Valco, 424 U.S. 1, 58-59 (1976)) method of infuencing the governmental process. See Boone, 841 F.2d at 895 . Thus, if the official is regarded as financially interested, the situation presents a true confiict between the competitive process and political process which, where no market behavior is involved, the case law resolves on behalf of the political process by granting immunity. See supra text accompanying notes 205-06.

Although no petitioning immunity applies, some lower courts have held that bribing merely to procure a government contract does not amount to a Sherman Act restraint of trade. See generally Franklin A. Gevurtz, Commercial Bribery and the Sherman Act, 42 U. MIAM1 L. REv. 365, 373-95 (1987) (collecting and analyzing case law). But this view is not universal, and, would not, in any event, immunize the briber from liability under other antitrust statutes like the Robinson-Patman Act or the Federal Trade Commission Act. See id. at 366 n.3, 377. Moreover, in the cases finding no restraint of trade, arguably competition was not harmed because the bribe merely influenced which party got a government contract that would, no matter which party was chosen, have excluded competitors. These cases would thus secm inapplicable when instead the bribed government official does impose a clear restraint on competition, such as restrictions on price, output, or entry.

315. The Court did decide an antitrust case involving the bribery of a foreign official, ruling that the act-of-state doctrine provided no immunity because the suit was against those who bribed the official and thus did not require a court to declare invalid the official act of a foreign sovereign. See Kirkpatrick Co. v. Environmental Tectonics Corp., 493 U.S. 400, 405-06 (1990).

316. See California Motor Transp. Co. v. Trucking Unlimited, 404 U.S. 508, 513 (1972); Allied Tube \& Conduit Corp. v. Indian Head, Inc., 486 U.S. 492, 502 n.7, 504 (1988). This recognition of a bribery exception might seem to contradict the language in Allied Tube indicating that those urging valid public restraints enjoy absolute immunity for those restraints. Id. at 499 . The reconciliation is that a bribed governmental official is "private" within the meaning of antitrust immunity because he is financially interested and should thus enjoy no state action immunity. Consistent with this interpretation, the Allied Tube case cited the bribery exception along with Continental Ore to support the proposition that "[ $t]$ he dividing line between restraints resulting from governmental action and those resulting from private action may not always be obvious." See id. at 501-02 \& n.7; see also id. at 501 (holding that the association was not public because the decisionmaking body comprised "persons with cconomic incentives to restrain trade"). Another possible doctrinal reconciliation is that bribery does not constitute merely "urging" governmental action.

317. This of course does not mean that antitrust immunity would extend to the direct effects of such illegal petitioning (as opposed to the effects of governmental action), but the Omni case did not concern such direct effects. See supra text accompanying notes 81-82.

318. See City of Columbia v. Omni Outdoor Advertising, 111 S. Ct. 1344, 1353 (1991) (stating that state action immunity would still apply); see also id. at 1355-56 (incorporating this proposition by reference for petitioning immunity). 
no evidence the defendant had engaged in bribery, ${ }^{319}$ but the Court's reasoning is nonetheless worth exploring because, to the extent it indicates the present Court's opinion on the subject, it nay represent a departure from the functional process approach.

The Court listed three reasons for its conclusion. First was that proving bribery or other independent legal violations bears no relation to the purposes of the Sherman Act. ${ }^{320}$ But one cannot indiscriminately lunip bribery together with other legal violations. While other legal violations may in fact bear no relation to the purposes of the Sherman Act, ${ }^{321}$ bribery does. This is not because bribery violates other state and federal laws - that is besides the point. The distinctive feature of bribery is that it makes the decisionmaking process a financially interested one, and thus one that should be policed by antitrust to ensure that the con1petitive process is not needlessly undermined.

Second, the Court argued that bribery does not necessarily niean that the resulting governmental action is contrary to the public interest. ${ }^{322}$ But again this is besides the point. Antitrust review applies not because private restramts on trade are never in the public interest, but rather because financially interested parties generally cannot be trusted to determine which restraints are $\mathrm{m}$ the public interest and which are not. Nor does antitrust inimunity apply because governmental restraints are always in the public interest; it applies because disinterested acconntable decisionmakers are generally better positioned to decide which restraints are $\mathrm{n} 1$ the public interest than courts. Where the governmental decisionmaker has been bribed, the grounds for immumity are absent because the decisionmaking process is financially interested and thus can be iniproved by being subjected, via antitrust review, to the competitive process.

Lastly, the Court argued that it would be difficult to determine the effect of bribes when they are given to a minority of a multi-nieniber governnental body. ${ }^{323}$ Suppose, for example, a firm bribes five legislators and a law restricting trade to the firm's benefit passes by 53-47. Should the law be struck down on the theory that, had the bribed legislators voted the opposite way, the law would have failed 52-48? Or should one siniply strike out the bribed votes, concluding that the law would still have passed 48-47? Alternatively, one might conclude that the legislature as a whole is not financially interested unless a majority voting for

319. There was evidence of campaign contributions, but those stand on a different footing. See supra note 314.

320. See Omni, $111 \mathrm{~S}$. Ct. at $1353,1356$.

321. They do, however, bear a relation where they are used by actors with market power to impose direct costs or delays that hinder competitors. See supra text accompanying notes 245-55.

322. See Omni, $111 \mathrm{~S}$. Ct. at 1353.

323. See id.; see also 1 AREEDA \& TURNER, supra note 105, ๆ 204d, at 49-50 (discussing difficulties of establishing whether bribes caused legislation). 
the law has received a bribe. After all, with a majority of disinterested accountable supporters, one can hardly say that the concerns are the same as with a fully interested decisionmaker.

These problems are difficult, but do not justify granting antitrnst immunity whenever bribes are given to governmental actors. To begin with, the difficulties have no apphication where the sole governmental decisionmaker has been bribed. Nor do they justify denying an antitrust plaintiff damages from the briber and the bribed legislators for the harm caused by the legislative restramt. ${ }^{324} \mathrm{~A}$ closer question is whether these problems justify refusing to invalidate legislative restraints produced by partial bribery. But the arguments against invalidation are not, I think, ultimately persuasive given the process ideals that underlie the case law.

There may be considerable doubt about what would have actually happened without the bribery. But if an antitrust court strikes down a statute passed in part by financially interested legislators, the issue is effectively remanded back to the legislature to see whether it wishes to reenact the same statute. ${ }^{325}$ This latter decision will give us our best evidence of what would have happened without the bribery, and it coines from a decisionmaking process better than either a partially bribed legislature or a disinterested but unaccountable antitrust court. I thus conclude that antitrust courts should invalidate anticompetitive legislative restraints whenever legislators who could have potentially changed the result have been bribed. ${ }^{326}$

324. Cf. Kirkpatrick Co. v. Environmental Tectonics Corp., 493 U.S. 400, $405-06$ (1990) (holding that the act-of-state doctrine did not immunize a party who bribed a foreign official from antitrust liability). These damages should, however, cease for anticompetitive injuries suffered after a disinterested legislature has been alerted to the past bribery but declined to repeal the legislative restraint.

In any event, even if, under $O m n i$, antitrust immunity applies to statutes procured by bribery, nothing in the opinion suggests this immunity should extend to any direct effects of the petitioning. Bribery should thus be sufficient grounds (as a means of petitioning that is invalid in all contexts) to impose liability on the petitioner for injuries caused not by the legislation, but by any reputational injury or costs and delays imposed by the bribing petitioner. See supra Part IV. This would include liability for the costs of opposing the bribing petitioner in governmental fora.

325. Damages, treble or single, would not and should not be available against the legislature or the state because they would injure taxpayers whom the government restraint did not benefit and indeed may well have harmed as consumers. See Elhauge, supra note 25 , at 735,736 n.322.

326. The ancient case of Fletcher v. Peck, 10 U.S. (6 Cranch) 87 (1810), cited in Omni, $111 \mathrm{~S}$. Ct. at 1353, is not to the contrary. The history of the dispute in Fletcher began when some buyers got the Georgia Legislature to sell them state land by promising numerous legislators parts of the land. See 10 U.S. ( 6 Cranch) at 129 . The buyers then re-sold the land to bona fide purchasers who did not know the land was originally procured by bribery. Id. When the bribes came to light, the Georgia Legislature responded by passing an act annulling the original sale. See id. at 131 .

The relevant questions before the Court were whether a downstream bona fide purchaser should be divested of title to the land either because the "corruption" of the Legislature made the original sale inherently void or because the statute annulling the sale was constitutional. In the course of holding that the purchaser's title was unaffected, the Court did express concern about what to do if a minority of legislators are bribed and how to decide what should be sufficient corruption to invalidate a statute. See id. at 130 . But these concerns were asides, on which the Court explicitly 


\section{Lies, Damned Lies, and Statistics}

Many cases have held that a petitioner who knowingly subinits false information to a governinental decisionmaker is not inmune from antitrust liability. ${ }^{327}$ The grounds for these decisions have not, however, been well articulated. Usually they proceed on the unelaborated assertion that such activity is a sham, but this is not very helpful as we have seen above. Nor have the courts been very precise in distinguishing between anticompetitive injury that resulted directly from the defendant's conduct-such as the costs of uncovering the true facts and opposing the defendant's facts or petition when that would have otherwise been unnecessary - and antitrust injury that resulted from a restraint the government imposed in a decisionmaking process infected by the false information. ${ }^{328}$ Allied Tube, which inakes petitioners absolutely immune for restraints resulting froin valid governinental action but liable for restraints directly resulting from invalid petitioning, highlights the crucial nature of this distinction.

Where the injury is direct and the lies are illegal under other laws, as they are in adjudication or regulatory proceedings, antitrust immuinty is inapplicable, ${ }^{329}$ just as it is for direct injuries resulting from abuses of process. ${ }^{330}$ This direct injury might, for example, consist of the costs of countering the defendant's false information in agency proceedings. ${ }^{331}$

The more difficult question is whetler, and when, the petitioner sliould be liable for governmental restraints adopted in response to his false petitioning. Clearly, petitioners are generally not liable for governmental responses to invalid petitioning. ${ }^{332}$ But iminunity might be denied on two doctrinal grounds: (1) that governmental action procured

did not rely, in an opinion mainly concerned about the inequities, and unconstitutionality under the Contracts Clause, of allowing courts or the state to annul a prior conveyance of title now held by a bona fide downstream buyer because of alleged corruption iu a prior legislature. See id. at 129-39. These inequities have no necessary connection to the bribery of legislators. The same inequities have led courts to protect bona fide purchasers when past title transfers that on their face looked legal were procured by mere private fraud rather than by bribing public officials. See id. at 133-35. And these inequities are not nearly so weighty when the question is not whether to deprive a bona fide purchaser of title but rather whether to remove a present legislative restraint on competition.

Fletcher is thus not binding on the antitrust issue discussed here. Nor are the concerns it expressed persuasive on that issue. The first concern, about how many legislators must be bribed, is addressed in text. The second conceru, about how much corruption should be enough, is a powerful arguinent against a court simply striking down a statute because of what it finds to be "corruption." But in Fletcher there was no legal or constitutional authority to invalidate the legislation for corruption. Here antitrust provides the authority and defines the type of activity within its scope.

327. See AREEDA \& HovenKAMP, supra note 10, 7204.1 , at $68 \mathrm{nn} .1-2$ (collecting cases).

328. See Calkins, supra note 9, at $342 \&$ nn. 78 \& 80-81 (collecting cases).

329. Accord AREEDA \& HovenKAMP, supra note 10, 1 204.1e, at 73-74.

330. See supra Section IV.C.2.

331. The injury will only be anticompetitive, however, if the defendant has the market power to take advantage of his rival's cost incrcases. See supra text accompanying note 254.

332. See Allied Tube \& Conduit Corp. v. Indian Head, Inc., 486 U.S. 492, 499-511 (1988) (denying imınunity to defendant for damages resulting directly from petitioning activity invalid 
by fraud is not "valid"; or (2) that a restraint does not truly "result from" governmental action when that action is procured by private fraud. Formal logic, however, cannot tell us when governmental action that does not itself violate any mdependent rule of law should nonetheless be considered "mvalid" under antitrust law because of the type of petitioning that procured it. Nor can it tell us who "caused" an injury. ${ }^{333}$ Rather, both sorts of doctrinal questions inust be settled by functional factors. The functional questions are the familiar ones: whether we have the assurance normally provided by a disinterested accountable decisionmaking process, and if not, whether that process would be improved by judicial antitrust review.

At one pole, consider deceptive coinments inade in the political process. These might admittedly mislead legislatures. But the social facts upon which legislative decisions are made are highly contestable. One is reminded of Disraeli's famous statement that "there are three kinds of lies: lies, damned hes, and statistics." 334 It is hard to find any policy debate where one side does not accuse the other of distorting the statistical evidence. That is the normal process of fighting for public opinion. ${ }^{335}$ Allowing antitrust courts to review the accuracy of political statements would not only chill political debate generally, but distort the debate by penalizing those stateinents with which the courts did not agree. Indeed, immunity for governmental acts produced by allegedly false statements in the political process follows a fortiori from the immunity for the direct effects of such stateinents. ${ }^{336}$

At the other pole, consider cases where the government has in effect delegated to a financially interested party the factual determinations that trigger governmental action. This situation is illustrated by Walker Process, ${ }^{337}$ where the antitrust defendant allegedly obtained a patent by filing false information witl the Patent Office and then enforced the patent by instituting a patent infringement suit that was not ultimately adjudicated because the patent expired before the case could be adjudicated. The functional process approach allows us to reconcile the Walker Process Court's holding - that proving these allegations would make the defendant liable under the Sherman Act for the damages caused to the plaintiff by the existence and enforcement of the patent-with the

within its context but stressing that no damages were predicated on harm caused by governmental restraints adopted in response to the invalid petitioning).

333. See supra text accompanying notes 311-13.

334. ResPectFully QuOTED 333 (Suzy Platt ed., 1992).

335. See AREEDA \& HovenKAMP, supra note 10, $\$ 204.1 \mathrm{c}$, at 70.

336. See First Am. Title Co. v. South Dakota Land Title Ass'n, 714 F.2d 1439, 1447 (8th Cir. 1983) (allowing immunity where the antitrust plaintiff had "equal access to the legislature to lobby against the [proposed legislation] and to correct any 'misrepresentations' which may have been made"), cert. denied, 464 U.S. 1042 (1984); Mark Aero, Inc. v. TWA, 580 F.2d 288, 297 (8th Cir. 1978) (no antitrust liability for lies told to city officials); supra Section IV.C.1.

337. Walker Process Equip. Co. v. Ford Mach. \& Chem. Corp., 382 U.S. 172 (1965). 
Court's repeated statements in other cases that petitioners are immune from antitrust liability for governmental acts.

In Walker Process, the relevant governmental action, granting the patent and then enforcing it pending adjudication, did not rest on any substantive decision by a disinterested official about the accuracy of the defendant's patent filing. Such filings are ex parte, and while the Patent Office can check its own records, it lacks access to other information that would be necessary to disprove a filing's assertions. ${ }^{338}$ In effect, then, for facts not covered by its own record, the Patent Office determined whether, given the defendant's filimgs, the invention was patentable. Accordingly, the Patent Office had effectively delegated to the antitrust defendant the factual determinations necessary to gain a patent. When, in such cases, the antitrust defendant falsifies the information, the governmental action is being triggered by a financially interested decision, and antitrust review should apply. ${ }^{339}$

The Walker Process exception for false petitioning is thus very narrow. It apphies only when the lie effectively results in a restraint produced by a financially interested process because the government has delegated to financially interested parties the factual determinations that trigger the governmental restraint. ${ }^{340}$ Thus, in such a case, one could say that the restraint results "directly" from the lie, ${ }^{341}$ just as one says that the costs and delays imposed by litigation result "directly" from a litigant's decision to bring strategic litigation. ${ }^{342}$ But it is the implicit functional process view that leads to these doctrinal conclusions.

Between these two poles are adjudications where lies could have been challenged by opposing hitigants but nonetheless succeeded in procuring adjudicative action that restrained trade. Because, unlike legisla-

338. See 3 AREEDA \& TURNer, supra note 105 , $\{707$ a, at 134 (1978).

339. If the lie did not trigger the government action because the invention would have been patentable even with accurate information, antitrust immunity would apply to the patent restraint on competition. See 3 id. \| 707d, at 137-38. Enforcement of the patent might, however, be denied as a matter of patent law. See 3 id. \| 707b, at 135-36. There might also be occasions where the false procurement of a patent does not result in any harm to competition, such as when the only effect is to alter which firm gets a monopoly. See AREEDA \& HovenKAMP, supra note 10, 凤 707'd, at 58889.

340. See also Woods Exploration \& Producing Co. v. Aluminum Co. of Am., 438 F.2d 1286, 1292-98 (5th Cir. 1971) (denying antitrust immunity to lying petitioner where the agency apportioned allowable production levels based on producers' forecasts of how much gas they were capable of producing), cert. denied, 404 U.S. 1047 (1972); Outboard Marine Corp. v. Pezetel, 474 F. Supp. 168, 178 (D. Del. 1979) (emphasizing that the defendant would be liable for submitting false information to the Treasury only if the Treasury made no independent inquiry but rather relied heavily on the defendant's submission).

341. See Woods Exploration, 438 F.2d at 1295 (concluding that because the agency relied on the defendant's false statement, the action could not be "said to have fiowed from state rather than private action"); Outboard Marine, 474 F. Supp. at 178 (suggesting that a Treasury decision would not be "the product of agency action" if the Treasury made no independent factfinding but simply relied on the defendant's false information).

342. See supra text accompanying notes 241-43. 
tors, judges and agencies adjudicate on a formal record often accompanied by a statement of reasons for the decision, it is easier to determine whether the lie affected the result. ${ }^{343}$ Further, the veracity of adjudicative facts tends to be less debatable than that of social facts. But antitrust review would nonetheless be mappropriate. The reason is not that the standards of conduct are lower in adjudication than in ex parte administrative processes like those in Walker Process. Rather, the reason is that a disinterested government official has made a substantive determination about the facts, in a forum that provided an interested opponent with the opportunity to dispute the alleged lies. Antitrust review in such circumstances would not so much police financially interested decisionmaking as it would substitute decisionmaking by antitrust courts for decisionmaking by the first court. Nothing in the antitrust statutes authorizes that substitution, and nothing in the objective process ideals suggests the substitution would be desirable.

\section{CONCLUSION}

Definmg the scope of antitrust petitioning immunity is not just a question of reconciling antitrust concerns about free competition with First Amendment concerns about the freedom to petition. Antitrust immunity extends beyond First Amendment protections because the competitive process guarantees of antitrust are fundamentally inapplicable to dismterested accountable governmental processes of decisionmaking. From a functional process perspective, courts adjudicating antitrust immumity issues emerge as the switchmen of democratic capitalism: guiding decisionmakers down the tracks of either the competitive or governmental process depending on which is most appropriate, but not substituting a track of judicial decisionmaking for either process.

This functional process approach fits and explains the result in every Supreme Court case adjudicating antitrust petitioning immunity. It also justifies many features of current doctrine. It justifies the Court's refusal to assess the substantive merit of restraints produced by disinterested accountable decisionmakers. It justifies the Court's focus on the objective incentives, rather than subjective motives, of decisionmakers. And it justifies the Court's refusal to second-guess the prevailing standards for providing input into alternative decisionmaking processes. Alternative positions on all these issues would embroil antitrust courts in making substantive decisions about how societal resources are allocated rather than allowing the political or competitive process to make those decisions.

Further, the functional process approach resolves many doctrinal questions and anomalies. It explains why some market activities are con-

343. See 1 AREedA \& TURNER, supra note 105 , 7 204c, at 48-49; 1 id. If 204d, at 50. 
sidered "commercial" and others not. It explains when restraints are "incidental" to petitioning, and when they "directly result" from that petitioning rather than from governmental action. It also explains how to determine whether the petitioning is "valid" for the purposes of antitrust immunity, particularly where strategic litigation is alleged. Finally, it helps resolve a host of still open questions about how the Court should treat petitioning that involves either boycotts aimed at private parties or bribes and lies that influence governmental decisions.

Perhaps most fundamentally, the objective process approach permits a more accurate understanding of the relationship between antitrust petitioning immunity and antitrust state action immunity. These immunities are not, as has so often been asserted, inere flip sides of each other. State action inmunity soinetimes applies when petitioning inmunity does not, and vice versa. But the two immunities do both share the basic functional process view that the coinpetitive process imposed by antitrust law is only necessary, and useful, when financially interested decisionnnaking is afoot. 
